\title{
$\wedge 11$
}

\section{الإنسانيات في فكر الأشاعرة والماتريدية مناقشات وردود}

إعداد

ote

أستاذ العقيدة والقلسفة المساعد كلية أصول الاين والاعوة بالزقازيق جامعة الأزهر

$$
\text { 9. من }
$$


A Y

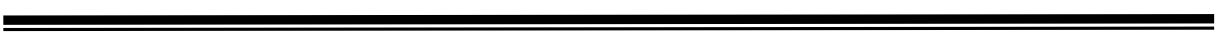




\section{The Humanities in Ash'ari and Maturidi Thought systematic vision}

Prepared by

Dr. Mustafa Mohamed Yahya Abdo

Assistant Professor of Doctrine and Philosophy

Faculty of Fundamentals of Religion and Dawah, Al-

Azhar University, Zagazig 


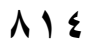

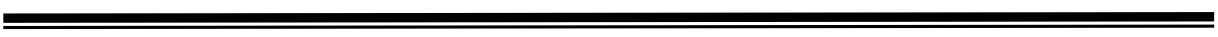




\section{الإنساتيات في فُكر الأشـاعرة والماترياية \\ مناقشنات وردود}

مصطفى محمد يحي عبده

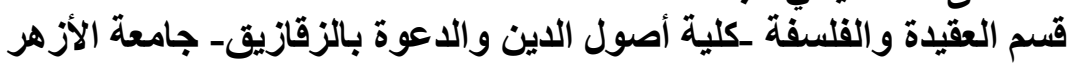

البريد الإكتروني:فustafa.mohamed@azhar.edu.eg

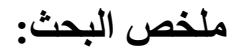

فإن قضية الانساتيات أو كمـا يعبر عنهـا في علـم الكـلام بأفعال العباد، أو الفعل

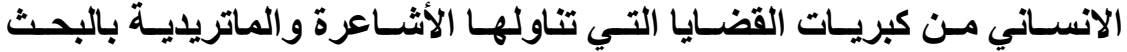

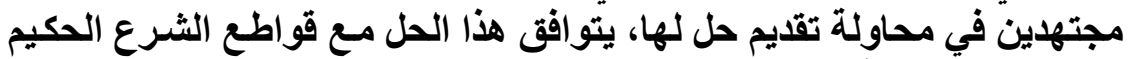

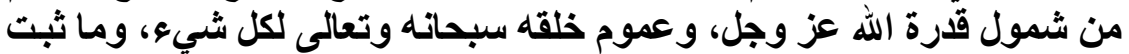

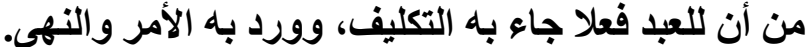

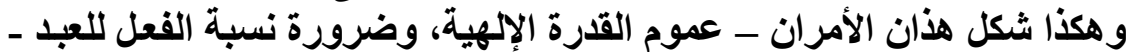

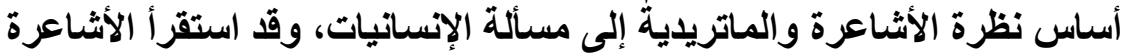

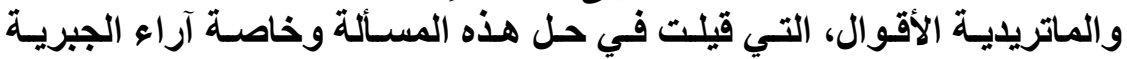

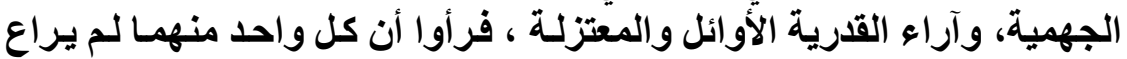

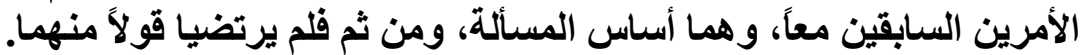

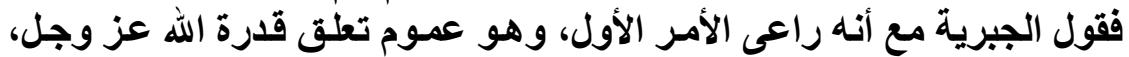

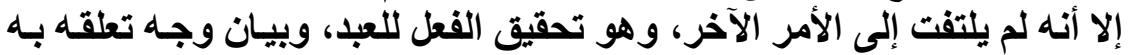

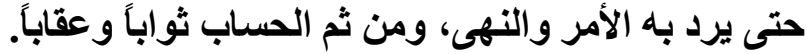

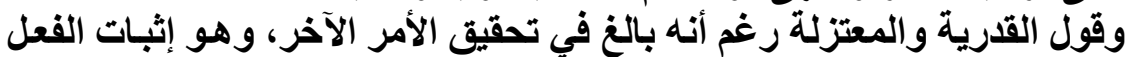

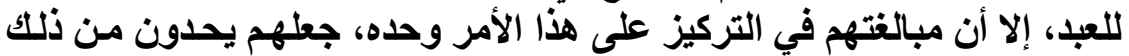

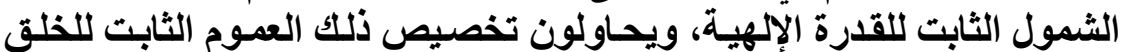

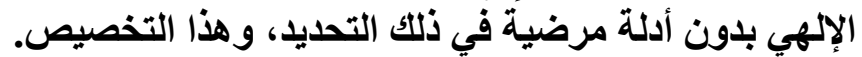

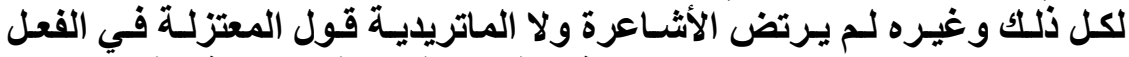

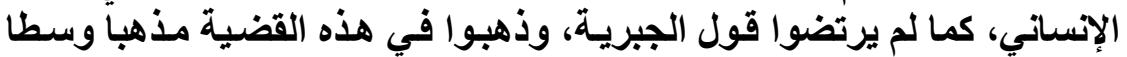

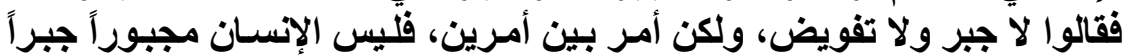

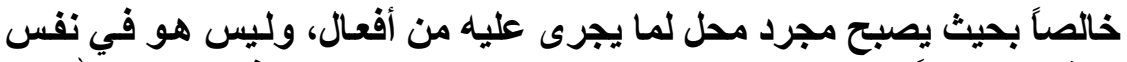

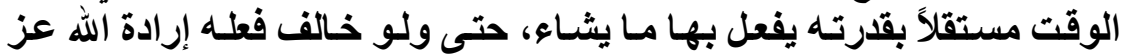

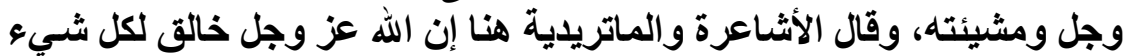

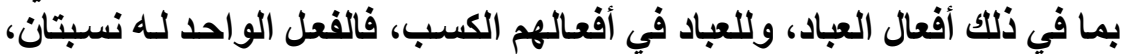

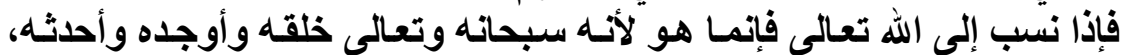

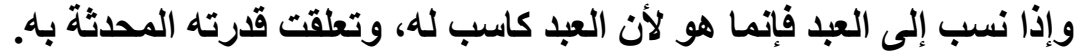

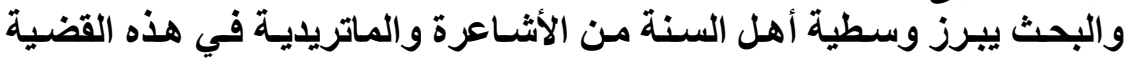
المهمهة من قضايا علم الكلام. الكلمات المفتاحية:الجبرية ـ القدرية ـ الأثاعرة ـ الماتريدية ـ أفعال الإنسـان 


\begin{abstract}
The Humanities In Ash'ari And Maturidi Thought Systematic Vision

Mustafa Mohamed Yahya Abdo

Department Of Doctrine And Philosophy-Faculty Of Fundamentals

Of Religion and Dawah, Zagazig, Al-Azhar University

Email: Mustafa.mohamed@azhar.edu.eg

Abstract:

The issue of the humanities, or as it is expressed in the books of theology with the actions of the servants, or the human act is one of the major issues that the Ash'aris and Maturidis dealt with in research, striving to try to provide a solution to it, so that this solution conforms to the decisiveness of the wise Sharia from the comprehensiveness of the power of God Almighty, and the generality of His creation, the Almighty. For everything, and what is proven that the servant has an act, the mandate came, and the command and prohibition came with it.

Thus, these two matters - the generality of divine power, and the necessity of attributing the act to the servant - formed the basis for the Ash'ari and Maturidi view of the issue of humanity. The two previous ones together, and they are the basis of the issue, and therefore they did not accept either of them.
\end{abstract}

So the saying of Jabriya considers the first command the generality of the power of God Almighty, and did not pay attention to the other command, which is the realization of the action for the servant, and the explanation of the aspect of his attachment to it until the command and prohibition are returned to it, and then the account is a reward and punishment.

And the saying of the Mu'tazilites exaggerated the realization of the other matter, which is to prove the action of the servant, but that made them limit that fixed comprehensiveness of the divine power, and they try to allocate that fixed generality of the divine creation without satisfactory evidence in that specification, and this specification.

For all that and others, the Ash'aris and the Maturidis did not accept the statement of al-Jubayrah or the saying of the Mu'tazilites in human action, and they unanimously agreed in this regard that there is neither compulsion nor authorization, but a matter between two things. Earning A single action has two attributes, so if it is attributed to God Almighty, it is because God Almighty created it, created it, and brought it into being. The research highlights the moderation of the Sunnis from the Ash'aris and Maturidis in this important issue of theology.

key words:Jabriya - Qadariyyah - Ash'ari - Maturidih - Human Actions - Gain. 
المقدمةة

بسم الله الرحمن الرحيم

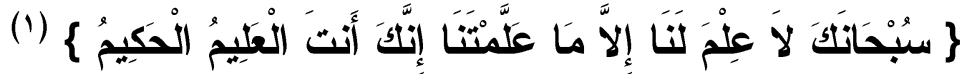

والصلاة والسلام على نبينا محمد وعلى آله وأصحابه أجمعين

وبعد فإن قضية الانسانيات أو كما يعبر عنها في علم الكلام بأفعال العباد، أو الفعل الإنساني من كبريات القضايا التي تناولها الأثـاعرة والماتريديــة بالبحث مجتهدين في محاولة ثقديم حل لها، يتوافق هذا الحل مع قواطع الشرع الحكيم من شمول قدرة الله عز وجل، وعموم خلقه سبحانه وتعالى لكل شيء، وما ثبت من أن للعبد فعلا جاء به التكليف، وورد بــه الأمــر

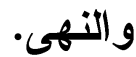

وهذا شكل هذان الأمران - عموم القدرة الإمهية، وضرورة نسبة الفعـل

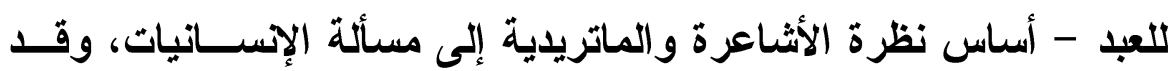

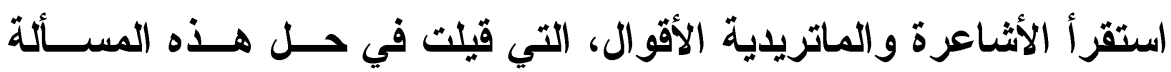
وخاصة آراء الجبرية، وآراء القدرية الأوائل والمعتزلة، فــرأوا أن كـل واحد منهما لم يراع الأمرين السابقين معاً، وهما أساس المسألة، ومن ثم فلم يرثضيا أحداً منهما. 
فققول الجبرية راعى الأمر الأول، وهو عموم تعلق قدرة الله عز وجل، إلا أنه لم يلتفت إلى الأمر الآخر، وهو تحقيق الفعل للعبد، وبيان وجه تعلقــهـ به حتى يرد به الأمر والنهى، ومن ثم الحساب ثو الاباً وعقاباً. وقول المعتزلة بالغ في تحقيق الأمر الآخر، وهو إثبات الفعل للعبد، إلا أن مبالغتهم في التركيز على هذا الأمر وحده، جعهم يحدون من ذلك الثمول

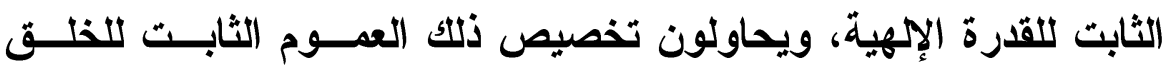
الإههي بدون أدلة مرضية في ذلك التحديد، وهذا التخصيص. لكل ذلك وغيره لم يرتض الأثثاعرة ولا الماتريدية قول القدرية ولا قــول المعتزلة في الفعل الإساني، كما لم يرتضوا قول الجبرية، وقاموا بمناقثة أدلتهم والرد عليها عقليا ونقليا، وأجمعوا في هذا الصدد على أنه لا جبر ولا تفويض، ولكن أمر بين أمرين، فليس الإنسان مجبوراً جبــراً خالصــاً بحيث يصبح مجرد محل لما يجرى عليه من أفعال، وليس هو في نفس

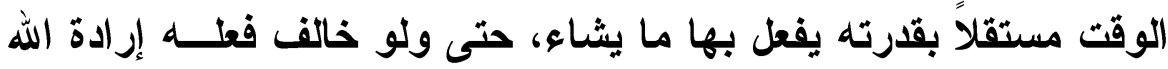

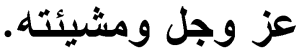

وقدم الأثثاعرة و الماتريدية في هذه القضية قولا وسطا يجمع بين النقـل و العقل، فأبقوا على كلية أن الله تعالى خالق لكل شيء بما في ذلك أفعـال العباد، وأثثبتوا أن للعباد في أفعالهم الكسب، به صـــح التكليـف، وعليـهـ يترتب الجزاء ثوابا وعقابا، فكان للفعل الواحد عندهم نسبتان، فإذا نســب إلى الله تعالى فإنما هو لأنه سبحانه وتعالى خلقه وأوجده وأحدثـه، و إذا نسب إلى العبد فإنما هو لأن العبد كاسب لله، وتعلقت قدرته المحدثة به. 


\section{9}

فرأيت أن مثل هذا الموضوع جدير بالبحث والاراسة لإبراز هذه الجهــود التي توافق فيها الأثـاعرة والماتريدية، وإبراز ما امتازوا به من طريقـــة للانقاش من أصحاب الأقوال المخالفة لهم فمن استدل بالنقل تعاملوا معسه بالنقل، ومن لجأ إلى العقل تعاملوا معه بالعقل، وقد حاولت قدر الامكــان جمع أقوال الأشاعرة والماتريدية في موضع واحد ما داما قد اتفقــا فـي ذلكك، أما اذا كان ثمة اختلاف بينهما فكنت أبين موضع الاختلاف بينهما. خطة البحث اشتمل البحث على تمهيذ وأربعة مباحث وخاتمة على النحو الآتي: تمهيد: حول تاريخ البحث في مسألة الإنسانيات المبحث الأول: موقف القدرية والجبرية من المسألة المبحث الثاني: قول المعتزلة في الفعل الإنساني: المبحث الثالث: المسأكة في فكر الأشاعرة والماتريدية:

المبحث الرابع: القدرة الحادثة و أثرها في الفعل الإنساني عنــــ الأثـــاعرة والماتريدية :

الخاتمة: وقد ذكرت فيها أهم نتائج البحث ثم ذيلت البحث بثبت لأهم المصادر

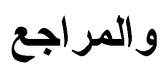




$$
\begin{aligned}
& \text { تمهيد: حول تاريخ البحث في هذه المسألة: } \\
& \text { أولا: مسألة الإسانيات قديمة - حديثة : }
\end{aligned}
$$

إنه وإن كنا معنيين بالارجة الأولى بتناول المسألة في فكر الأثشاعرة و الماتريدية، إلا إنه لابد من أن نثير إلى أن البحث في هذه المسألة قديم قدم

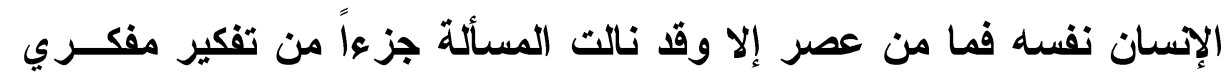
هذا العصر، فعلى سبيل المثال، بحث الفلاسفة اليونانيون قديماً هذه المسألة،

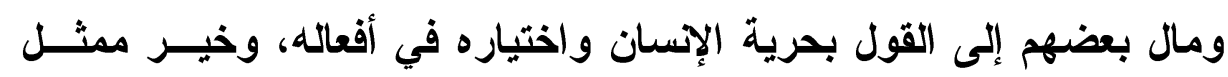

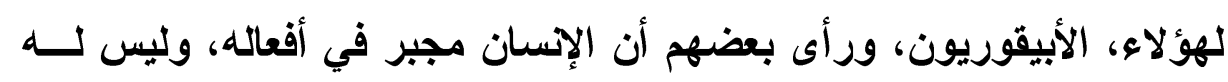
فيها إرادة ولا اختيار، ويمثل هؤلاء الرواقيون (1)

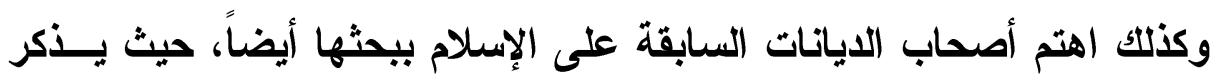
الباحثون في هذا الصدد أنه كان من بين اليهود من يقول بالجبر، كما كـــان

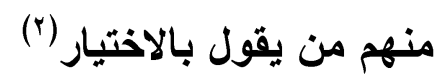

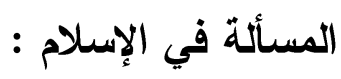

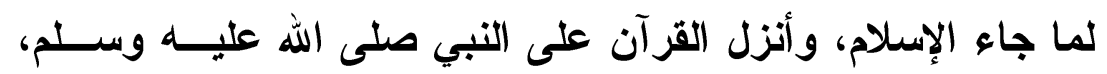

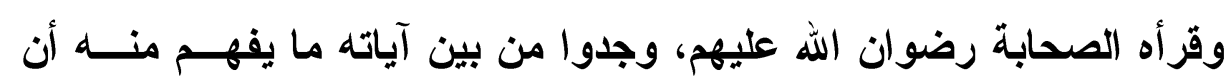

(') أفعال العباد أ.د/ سعد صالح، طدار الطباعة المحدية الأولى 9 ــ اهــ، صه، 9 بتصرف يسير.

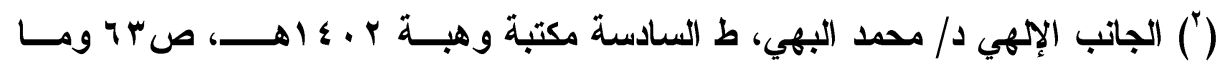
بعدها، وانظر تاريخ المذاهب اللثيخ محمد أبو زهرة ص ع 9 . 


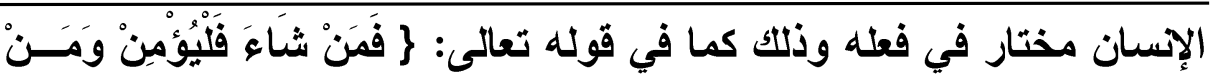

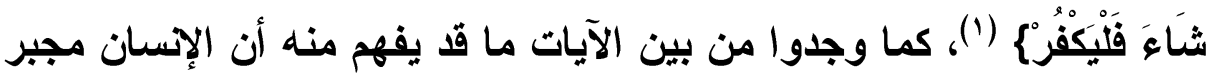

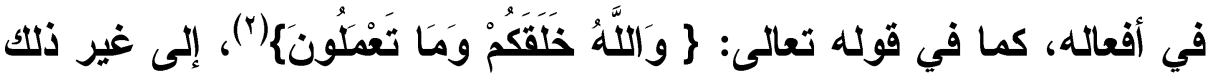
من الآيات، فاختلفت الأفهام تجاه ذلك حتى أوشك الأمر أن يحــدث اختلافــاً وتفرقاً بين المسلمين، ورأى رسول الله صلى الله عليه وسلم ما فــي هـــا الاختلاف من خطر على الأمة الإسلامية التي ماز الت في مهذها، فأر اد رسول الله صلى الله عليه وسلم أن يتلافى انشقاق الأمة بسبب إثارة هذه المشكلة، فكان ينهى دائماً عن إثارتها، وعن الجدل فيها("). فمن ذلك ما روى عن أبى عمرو بن شعيث عن أبيه عن جده قـال: "خــرج رسول الله صلى الله عليه وسلم على أصحابه وهم يختصمون فــي القــدر،

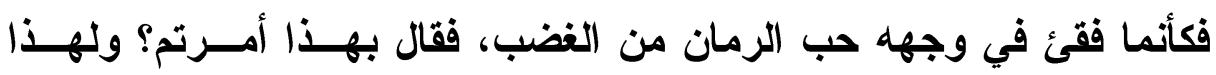
خلقتم؟ تضربون القرآن بعضه ببعض، بهذا هلكت الأمم قبلكم"(\&) يقول الثيخ أبو زهرة: فأقوى مسألة كانت هي مسألة القدر، وقد نهى النبي صلى الله عليه وسلم عن الخوض فيه، مع وجوب الإيمان به، لأن الخــوض فيه مضلة للأفهام، ومزلة للأقدام، وحيرة للعقول في مضطرب من المــذاهب

$$
\begin{aligned}
& \text { (') سورة الكهف / } 9 \text { ( ب . }
\end{aligned}
$$

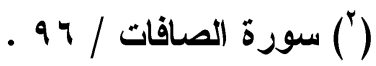

(") التفكير الفلسفي في الإسلام ا.د/ عبد الحليم محمود صVV وما بعدها بتصرف. (") العديث أخرجه : (بن ماجة في سنته كتاب الإيمان باب في القدر جـــ/ه ؛ وقــال البوصيري في مصباح الزجاج /1/1ه هذا إسناد صحيح رجاله ثقات. 
والآراء وذلك يدفع إلى الفرقة والاتقسام، ولأن إثارة الجدل فيه إثارة في أمر ليس في سلطان المجادل الإقناع فيه، وليس بيد أحد من الأدلة العقليــة مـــا يحسم به الخلاف ويقطع في الموضوع)". ولقد انصاع الصحابة رضوان الله تعالى عليهم لأمر الرسول صلى الله عليــه وسلم، فاتتهوا عن النزاع في القدر، وآمنوا بالقدر خيـره وشــره مـن الله تعالم، وفى ذلك يقول الإمام النووي عند شرحه لبعض أحاديث القدر "اعلــم أن مذهب أهل الحق إثبات القدر، ومعناه أن الله تبارلك وتعالى قدر الأثــياء في القدم، وعلم سبحانه أنها ستقع في أوقات معلومة عنده سبحانه وتعالى،

على صفات مخصوصة، فهي تقع على حسب ما قدرها سبحانه وتعالى (r) واستمر على ذلك الوضع السلف من الصحابة وخيار التابعين إلى أن حــثث بدعة القدر في أواخر زمن الصحابة(). ويؤكد الإمام عبد الحليم محمود أن اعتقاد الصحاب رضوان الله عليهم، كان ينحو نحو الاعتقاد، بأنه لا تطرف في العالم طرفة عين، ولا تهب فيه نسمة هواع، ولا يحدث فيه حادث صغر أو كبر إلا بإرادة وتقدير من الله سـبحانه وتعالى، وما ذلك إلا لأن فكرة الإلموهية قد ملأت قـــوبهم، وســيطرت علــى

$$
\begin{aligned}
& \text { (') تاريخ المذاهب صه } 9 \text {. }
\end{aligned}
$$

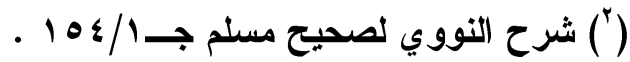

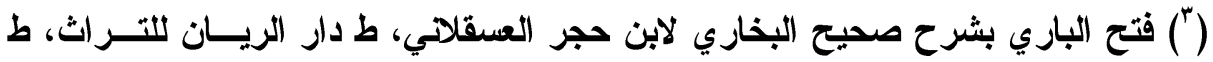

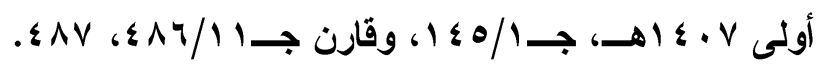


نفوسهر، فاستسلموا لله خاضعين مؤمنين بأن ما شاء الله كان وما لم يشأ لم يكن، واستسلامهم هذا الله، هو نفسه الذى دعاهم أن يعملوا، وأن يجتهـدوا

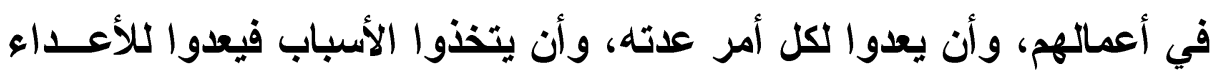
ما استطاعوا من قوة) ('). وبعد انتقاله صلى الله عليه وسلم إلى الرفيق الأعلى بدأت الأمور تختلـفـ،

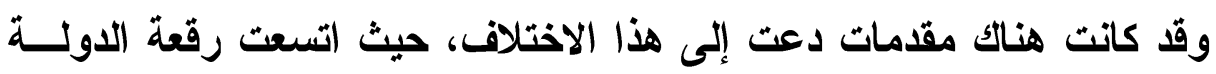
الإسلامية، وكثرت الفتوحات، واختلط المسلمون بغيرهم من الأمم، وبكثيــر من أصحاب الدياتات السابقة، وكان من هؤلاء من يتكلم في القدر، فمنهم من هن

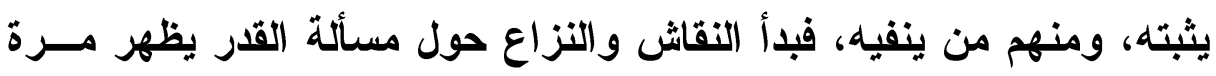
أخرى، حيث بدأ يظهر في الساحة الإسلامية من يتخذ من القدر مبرراً له في هئه

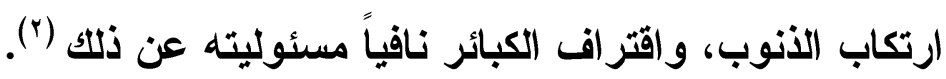
وكلما بعد العهد عن عصر رسول الله صلى الله وسلم، كانت المسألة تأخــــ

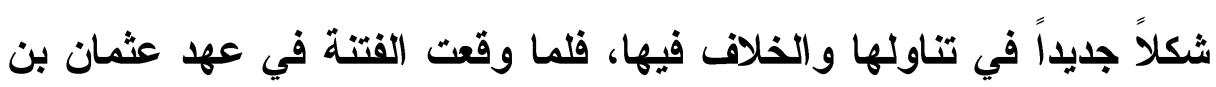
عفان وعهر على بن أبى طالب رضى الله عنهما، كثر النزاع جداً حول مسألة

(') التفكير الفلسفي في الإسلام صه9، و9 بتصرف يسير وقارن فتح الباري لابن حجر $0.1 / 11 \rightarrow$

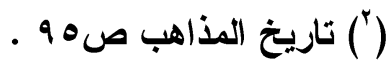


Ar $\varepsilon$

القدر، وكما يقال - الكلام في القدر يشتد كلما اتسع نطاق الفتن، ولذا كــان

الكلام فيه في عهر على أشد وأحد (1).

ويعتبر العلماء هذا العصر - عصر أواخر الصحابة - هو العصر الأى كثرت

فيه الاختلافات بين المسلمين(†)، وكاتت الاختلافات هذه المرة تحــدث فـي

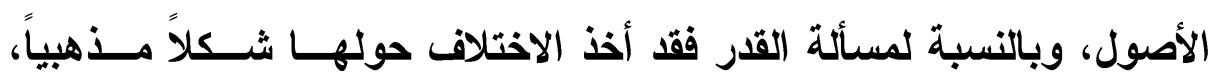
بمعنى أن يتحول الرأي إلى مذهب يكون له أنصاره ومؤيدوه (r)، وقـ تمثــل النزاع في القدر في هذا العصر في وجود تيارين متعارضين: الأول: هو تيار القدرية الأوائل، الأين زعموا أن الإنسان يأتي أفعالــهـ فــي حرية كاملة. والآخر: هو تيار الجبرية الجهمية الذين زعموا أن لا قدرة ولا إرادة للإنسان في أفعاله، وإنما هو مجرد محل لها.

$$
\begin{aligned}
& \text { (') (السابق صצ' } 97
\end{aligned}
$$

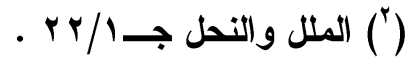

(") نشأة الآراء و المذاهب و الفرق الكلامية د/ يحيى هاشم فرغل صمه هـ 
المبحث الأول: موقف القدرية والجبرية من المسألة

أول من تكلم في القدر:

تجمع المصادر على أن أول من تكلم في القدر وأعلنه مذهباً هو معبــــــن

خالد الجهني كما في رواية الإمام مسلم (1).

وقوام مذهب القدرية هو أن الإسسان حر مختار في فعله، وحتـى لا تكــون هناك شبهة للجبر أو التعلل بالعلم القديم لله سبحانه وتعالى بما سيكون عليه

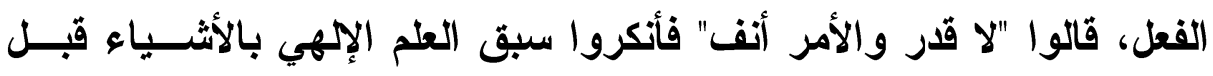

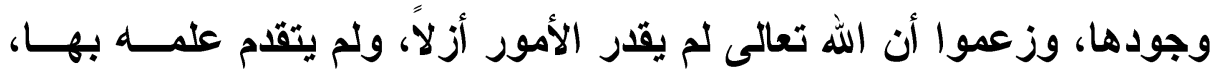

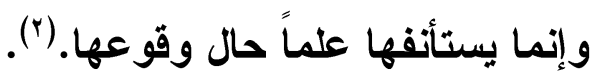

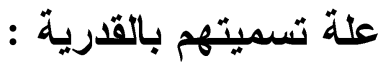
أطلق على هؤلاء القوم- لقب القدرية- مع نفيهم القدر مــن بـاب تســية الثيء بضده مبالغة في تمييزهم، وقال بعض العماء تسميتهم بالقدرية إنما جاءت من حيث نفوا القدر عن الله تعالى وأثبتوه للعبد، ويرى بعض ثالــث

(') الحيث أخرجه : مسلم بشرح النووي كتاب الإيمان بــاب بيـان الإيــان والإســلام

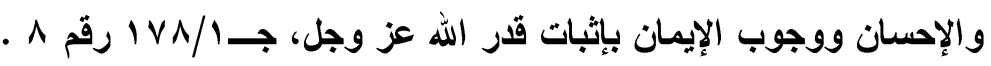

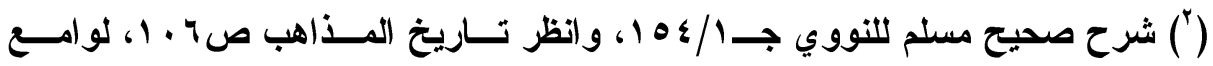

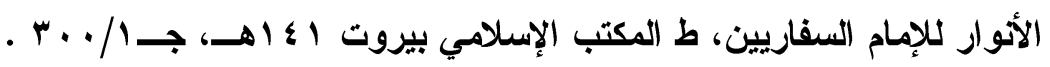


من العلماء، أن تسميتهم بهذا لما ورد في حليث "القدريــة مجـوس هــذه

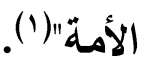

يقول الإمام البيهقي - وإنما سموا قدرية لأنهم أثثبتوا القدر لأفسهم، ونفوه عن الله سبحانه وتعالى، ونفوا عنه خلق أفعالهم وأثبتوه لأنفسهم، فصــاروا بإضافة بعض الخلق إليه دون بعض مضاهين للمجوس في قولهم بالأصــلين النور والظلمة، وإن الخير من فعل النور، والثر من فعل الظلمة"(†). مناقشة القدرية في قولهم : لا نريد أن نقف أمام هذا المذهب طويلاً لما يلى : أولاً : يصطدم هذا المذهب مع الآيات القرآنية التي تؤكد سبث العلم الإلهـي

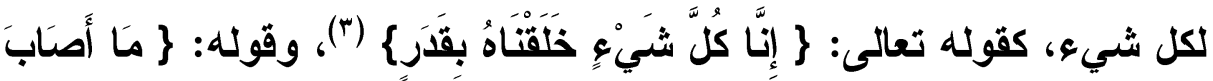

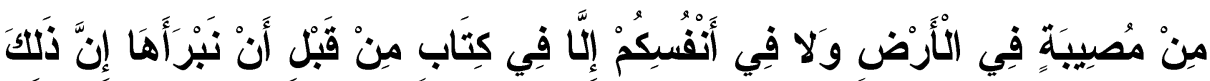

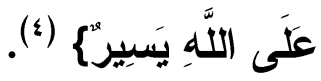

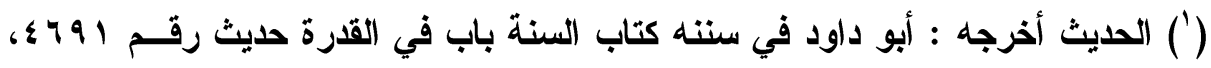

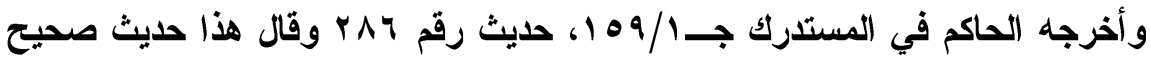
على شرط الثيخين إن صح سماع أبى حازم عن ابن عمر، ولم يخرجـاه، وواقـــهـ الأهبي في التلخيص على ما قال.

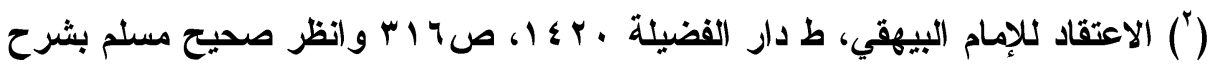
النووي جـ//ء 1، تاريخ المذاهب صף ـ 1 ـ (") سورة القمر / 9 ؛ .

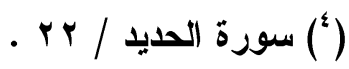


وقد رأينا قبل ذلك تأكيد التبي صلى الله عليه وسلم علــى وجــوب الإيمــان بالقضاء والقدر، وجعل ذلك ركناً من أركان الإيمان، ومن ثم فها المــذب

يتنافى مع ما قرره القرآن الكريم، وأكدته السنة النبوية الثريفة (1) ثاتياً : أن أصحاب المذهب قد انقرضوا، ولم يعد لهم وجود مما يــل علــى بطلانه في نفسه(r). ثالثا: الجبريــــــــة : بعد أن غالى معبد الجهني في القول بالاختيار، رأى بعض النــاس أن هـــا القول كأنه ينتقص من السيطرة الإههية المطلقة، فلما رأوا المغالاة في القول بالاختيار، ثارت ثائرتهم فنادوا بالجبر ودعوا إليه("). والجبر كما يعرفه الشهرستاني هو نفى الفعل حقيقة عن العبد وإضافته إلـى الرب تعالى - والجبرية الخالصة هي التي لا تثبت للعبد فعلاً ولا قدرة علـى الفعل أصلاً (؛) والجبرية الخالصة تزعمها ودعا إليها الجهم بن صفوان ومن

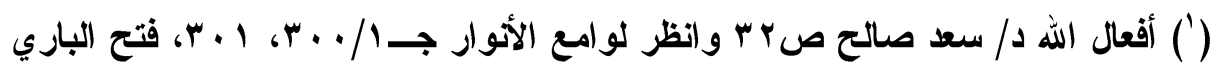

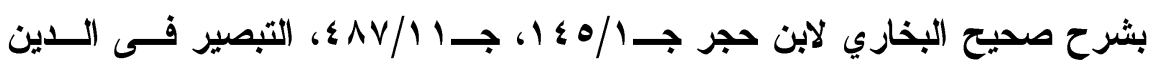

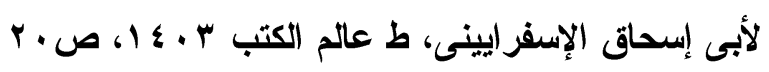

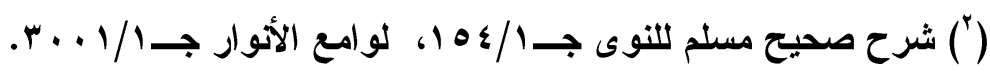

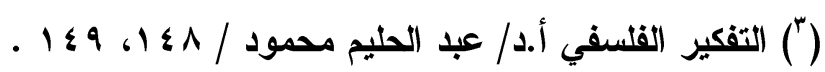

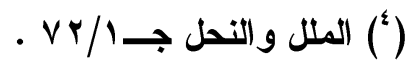


AYA

تابعه وحاصل مذهبه كما عبر عنه السنوسي هو: وجود الأفعال كلها بالقدرة

الأزلية فقط من غير مقارنة لقدرة حادثة"(1)

وبذلك لم يفرق الجبرية بين ما هو اختياري من أفعال الإسسان وبين ما هــو اضطراري منها بل جعلوا العباد كما يقول البغدادي "مضطرون إلى الأفعسال المنسوبة إليهم، وليس لهم فيها (كتساب(؟). ويؤكد الإمام النسفي فيقول "وزعمت الجبرية أن أفعال الخلق كلها لله تعالى، وهى كلها اضطر ارية، لا اختيار للخلق فيها ولا قدرة كحركات المرتعش (†) قوام مذهب الجبرية : - ماية

إن قوام مذهب الجبرية هو أن الأفعال إنمـــا تنسـبـ إلـــ الإنســان

باعتباره محلاً لها فقط، وليس للإنسان دخل فيهـــا ألبتــة، فــلا قــدرة ولا استطاعة ولا اختيار أصلاً وإنما يخلق الله تعالى، الأفعال فيه على حسب مـــ يخلق في سائر الجمادات"(๕).

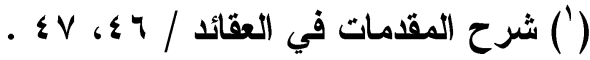

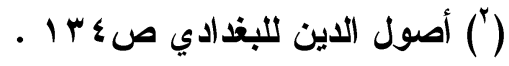

(") التمهيد لقواعد التوحيد لأبى المعين النســفي، تحقيـق د / جيـب الله حســن أحمـــ ص PVV

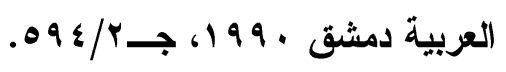

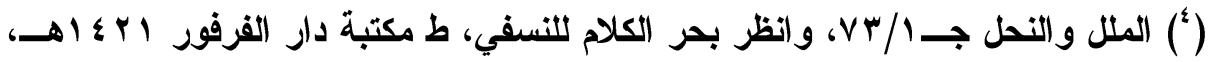




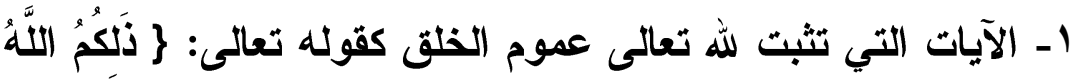

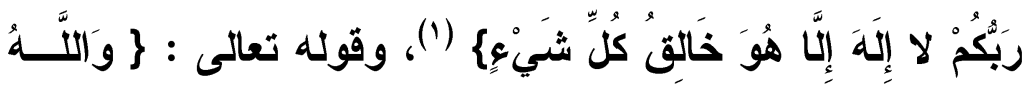

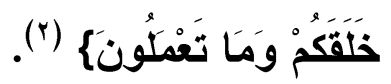

r- قالوا إن في تحقيق الفعل ونسبته إلى العبد، يؤدى إلى أن يكون

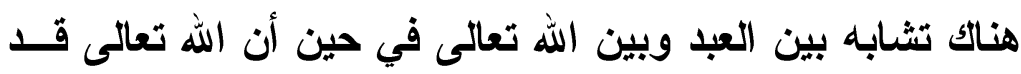

نفى ذلك بقوله تعالى

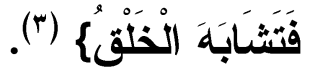

إذا فمنهج الجبرية في الاستدلال على قولهم إنما هو التركيز علـى الــلائل الموجبة دخول الأفعال تحت قدرة الله تعالى، فتمسكوا بتلك الالائل، وجعلــوا الأفعال مخلوقة لله تعالى خارجة عن أن تكون مقدورة لغيره لاستحالة تعلق

قدرة غير الله تعالى بما تعلقت به قدرة الله تعالى (๕).

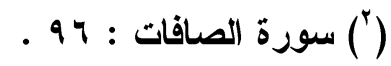

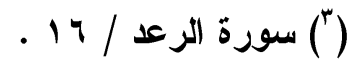

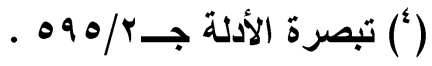


مناقثة أقوال الجبرية :

نستطيع القول بأن الجبرية قابلوا غلواً بغلو، وتطرفاً بتطرف، فكما بالغ معبد في تحقيق الفعل للإنسان لتأكيد مسئوليته عنه حتى أداه ذلك إلى نفى القـــدر السابق، بالغ جهم في تحقيق الفعل لله تعالى وإبعاد الإسسان عن أن يكون له

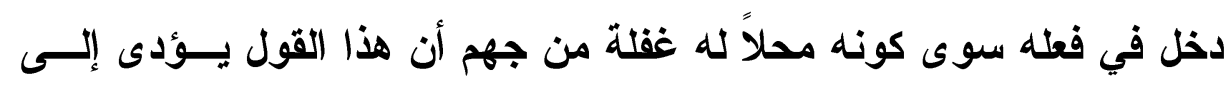
بطلان التكليف وحقاً ما يقول أبو المعين النسفي إن كل فريق نظر إلى الأدلة

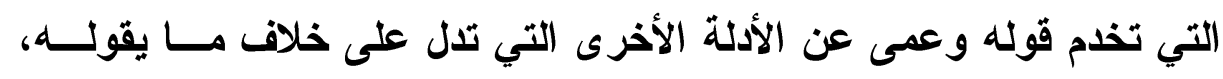

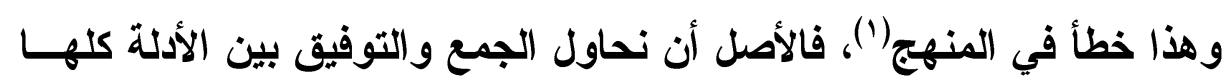
ولا نهمل شيئًا على حساب شيء آخر.

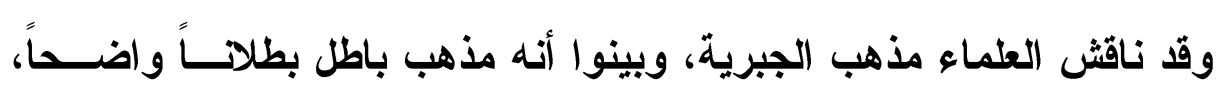
ودللوا على بطلانه بدلالة السمع، ودلالة العقل، ودلالة الضرورة.

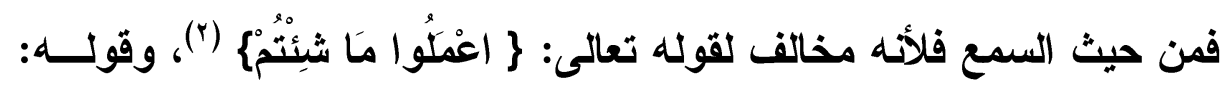

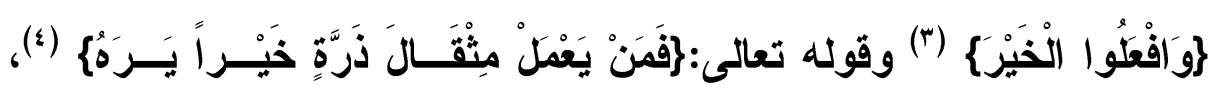

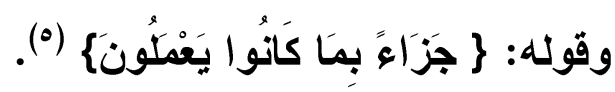

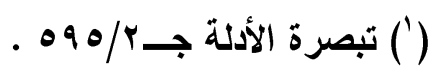

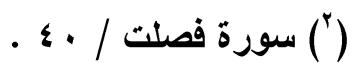

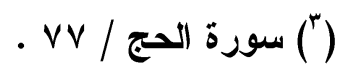

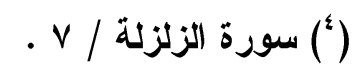

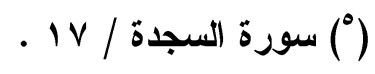


ومن حيث العقل، فلأنه لو لم يكن للإنسان في فعله مدخل أصلا، لا قدرة ولا اختياراً، ولا كسباً، لأدى ذلك إلى بطلان الأمر والنهى، حيث لا فعل للمـأمور

أو المنهى (1) - (1)

أما من حيث الضرورة، فيقول السعد "هو باطل لأنا نفرق بالضــرورة بـين حركة البطش، وحركة الارتعاش، ونعلم أن الأول باختيارنا دون الثاني"().

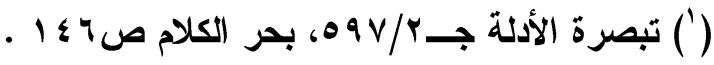

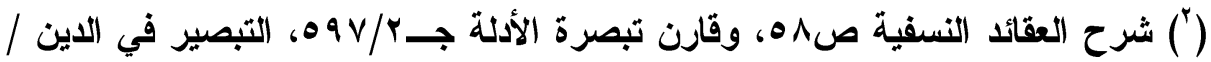

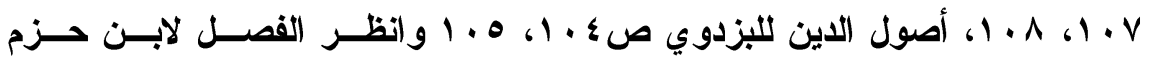

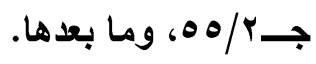


المبحث الثاني: قول المعتزلة في الفعل الإسكاني:

قضية أفعال العباد تعتبر ركيزة من الركائز التي يقوم عليها الفكر الاعتزالي، وهى من القضايا ذات الثأن، فعلى أساس القول في افعال العباد تقوم قضايا كثيرة تدخل في صلب أو صميم المذهب الاعتز الي، حيث يقوم على قولهم في هذه المسأكة أصلان من أصول المعتزلة الخمسة، هما أصل العـدل وأصـل الوعد و الوعيد، فلقد كان من مقتضيات العدل عند المعتزلة أن الله تعسلى لا يخلق أفعال العباد، ومـا ذلتك إلا ليصح التكليف من جهة، ولكى ينــزه الفعـل الإههي عن القبائح والثرور التي تقع في أفعال العباد من جهة أخرى، وعلى

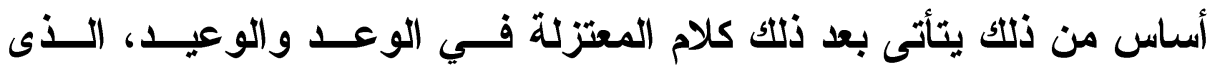
تستحوذ عليه فكرة استحقاق المكلف للثو اب و العقاب. ولقد وضع المعتزلة لأفسهم أصولاً وقواعد ينطلقون منها للكلام في أفــال العباد، محافظة منهم على العدل والحكمة الإهيتين، حيث قرروا من خـلال أصلهم الثاني —العدل- أن الله تعالى، عادل في أفعاله حكيم فــي تصــرفاته، ومن معانى العدل والحكمة أنه تعالى يفعل الحسن، ولا يفعل القبيح، ولما كان الله تعالى لا يفعل القبيح، فهو تعالى لا يظلم، فالظلم مما يدرك العقل قبحسه، و إذا كان الله تعالى لا يظلم، وكان في نفس الوقت قد كلف الإسسان بافعل ولا لهان تفعل، وسوف يحاسبه على أفعاله ثواباً أو عقاباً، رأى المعتزلة عند ذلك أنه يتحتم القول بأن الإسسان هو الذى يوجد فعله ويختاره لتصح كل هذه الأمور، يقول المسعودي: "وأما القول بالعدل، فهو أن الله تعالى لا يحب الفســاد، ولا 
يخلق أفعال العباد، بل يفعلون ما أمروا به، ونهوا عنه بالقدرة التي جعهــا

$$
\text { الله لهم "(1) }
$$

ويرى المعتزلة طبقاً لذلك أن القول بأن الله تعالى هو الـــى يخلـق الفعـل الإنساني، فيه إلحاق الظلم بالفعل الإلهي، وهو ما يكرس المعتزلة جهــودهم في تتزيه الله تعالى عنه، ومن ثم قرر المعتزلة أن العبد هو الأى يخلــث أو يوجد فعله الاختياري حتى تصح المسئولية، ويتأتى الثواب والعقاب، وحتـى لا يقطع المعتزلة العلاقة أو الصلة بين الفعل الإنساني والقدرة الإههية، نراهم - كما قال المسعودي في النص السابق يؤكــدون أن الإســــان إنمـــا يفـــل ويترك، بالقدرة التي أعطاها الله تعالى له. و انطلاقًاً كذلك من تركيز المعتزلة، على الاخول في مســألة أفعـال العبـاد، بقصد تصحيح مسئوليتهم عنها، نر اهم يفرقون بـين الفعـل الاضــطراري، و الفعل الاختياري فيقرون بأن الأول لا دخل للإنسان فيه، بل هو من فعل الله عز وجل، أما الآخر فلأنه مدار المسئولية والجزاء فهو الأى يوجده الإنسان ويختاره بقدرته التي أعطاها الله له(r). إجماع المعتزلة على هذا القول :

(') مروج الأهب للمسعودي، تحقيق/ محمد محي الـــين عبــــ الحميــد، ط المكتبــة

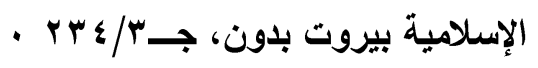

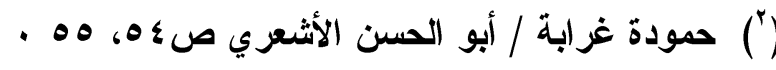


يكاد يكون القول بأن العبد هو الأى يوجد فعله باختياره، محل إجمـاع مسن رجال المعتزلة، يسجل لنا ذلك القاضي عبد الجبار" اتفق كل أهل العدل علــى أن أفعال العباد من تصرفهم، وقيامهم وقعودهم، حادثة من جهتهم، وأن الله عز وجل قد أقدرهم على ذلك، ولا فاعل لها ولا محدث سواهم"(1"). وقد مر كلام المعتزلة في التعبير عن أن العبد موجد لفعله بمرحلتين، أولاهما مرحلة المتقدمين من المعتزلة، وهؤلاء كانوا يقولون إن العبد يوجد فعلــه، ويتحاشون من إطلاق القول بأن العبد يخلق فعله، ولعل سبب ذلك كما يشير إمام الحرمين يرجع إلى قرب عهدهم بإجماع السلف على أنه لا خالق إلا الله

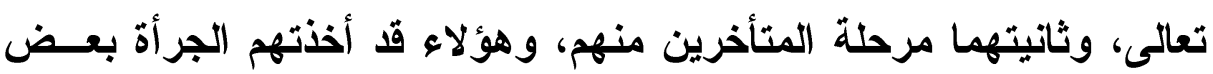
الثيء فسموا العبد خالقاً على الحقيقة"(r). يقول عبد الجبار موضحاً، بينا أن المخلوق لا يفيد أنه مخترع، ولا أنه مسن فعل الله تعالى، . . . . ودللنا على أن العبد في الحقيقة يوصف بأنــهـ يخـــق

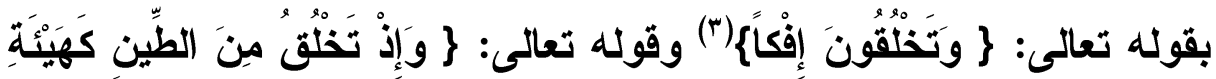

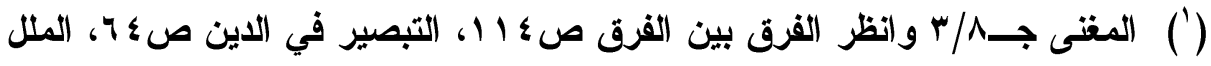

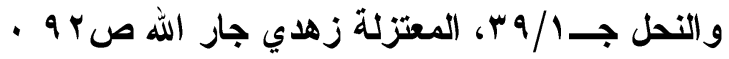

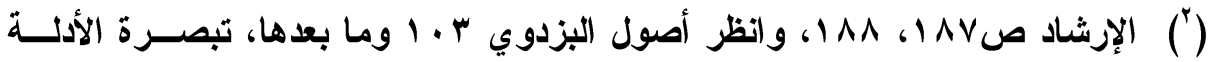
جـ

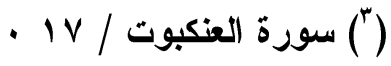




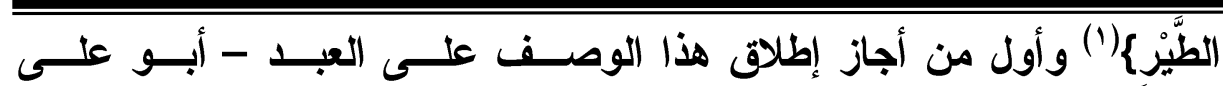

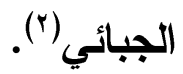

وينبغي أن نلاحظ أن متأخري المعتزلة عندما أجازوا استعمال، لفظ الخــالق في الإنسان، فإنهم إنما يستعملونه من حيث المعنى الأعــم للخلــق، وهــو

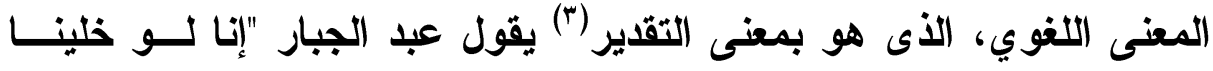
وقضية اللغة لأجرينا هذا اللفظ على الواحد منا، كما نجريه على الله تعـالى، لأن الخلق ليس بأكثر من التقدير"(؛). منهج المعتزلة في إثبات قولهم في الفعل الإساني: من المعتزلة من سلك مسلك الضرورة، وقال إن العلم بأن العبــاد يوجــدون أفعالهم علم ضروري، وأبرز من يمثل هذا الفريق - أبو الحسين البصـرى وأتباعه، يقول صاحب المواقف وشارحه "فأبو الحسين ومن تبعه يدعى في إيجاد العبد لفعله الضرورة، أي يزعم أن العلم بذلك ضروري لا حاجة به إلى

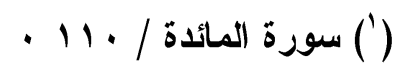

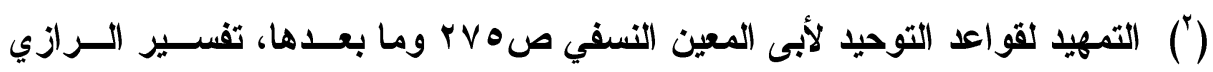

$$
\cdot 1 \cdot v / r \rightarrow
$$

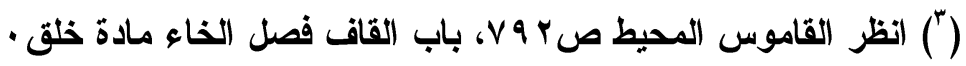

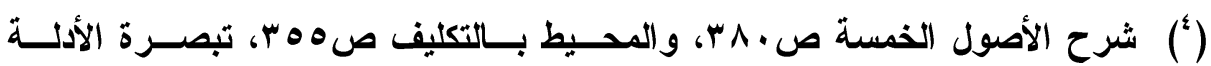

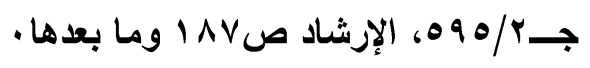


استـلال(') ولكن ينبه عليه بأن كل أحد يجد من نفسه التفرقة بـين حركتـي المختار والمرتعش، وبين الصاعد باختياره إلى المنارة والهاوي منها، ويعلم أن الفعلين الأولين - أي حركة المختار، وحركة الصـــاعد، يســتـدان إلــى دواعيه واختياره، وأنه لولا تلك الدواعي والاختيار لم يصدر عنــه شــيء

(r) مisم

مسلك سائر المعتزلة : رأى جمهور المعتزلة أن الحكم بكون العبد يوجد فعله الاختيــاري ويحدثــهـ، يحتاج إلى نظر واستـلال، يقول الإمام الرازي : "الطــائف الثانيــة : الــــين يقولون إن علمنا بكوننا موجدين لأفعالنا، علم استدلالي، وهذا مذهب جمهور

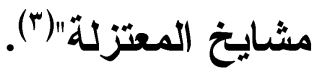
ومن أهم أدلة المعتزلة عي هذاهلة الصدد ما يلي: أولاًا : الأدلة العقلية :

كلام المعتزلة في هذا الصدد يرتكز على طريقين اثنين، أحدهما وقوع هـــا الفعل بحسب أحوالنا، وانتفائه بحسب أحوالنا، والثاني حسن الأمر والنهـى رئى

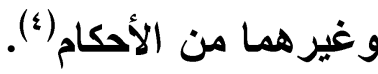

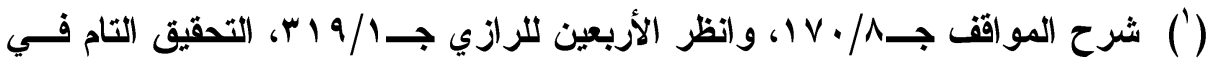

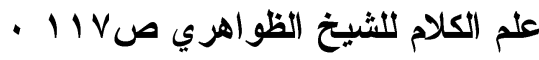

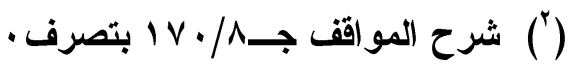

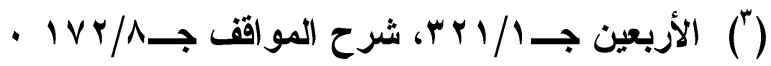

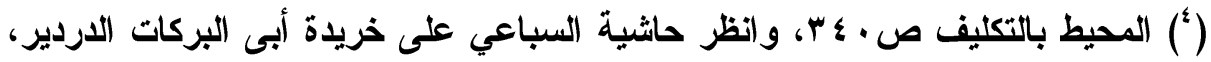

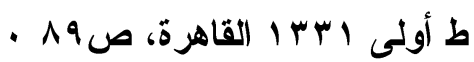


وتوضيحا للطريق الأولى:

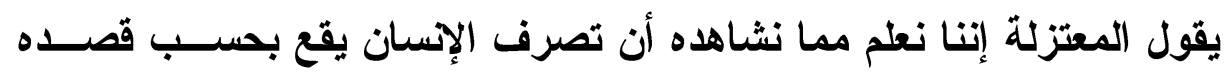

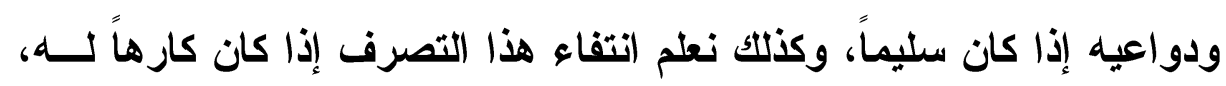

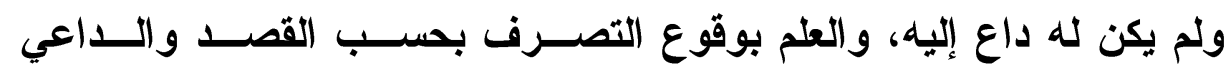
ضروري يقول عبد الجبار "إن العلم بوقوع تصرفنا بحسب دواعينا وقصودنا، وغير ذلك من أحوالنا، حاصل على وجه لا يمكن دفعه عن النفس(") وما وقع من تصرف الفاعل بحسب قصده ودواعيه، يجب أن يكون فعلاً له، وحادثاً من جهته، لأده لو لم يكن الأمر كنلك لأدى إلى أن الفاعل لا تعلق له له

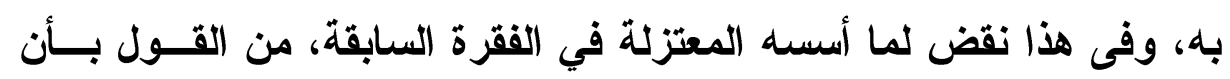
العلم بوقوع تصرف زيد بحسب قصده ضروري(ن) ويوضح قاضى القضاة هذا الأمر بطريقة أخرى فيذكر أن حاجة وقوع هــــه

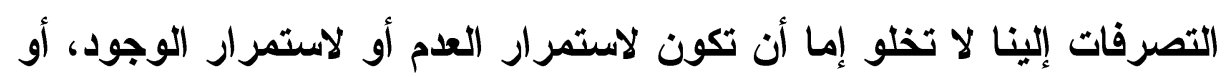

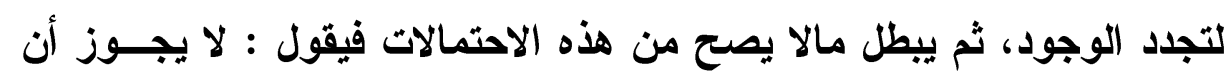

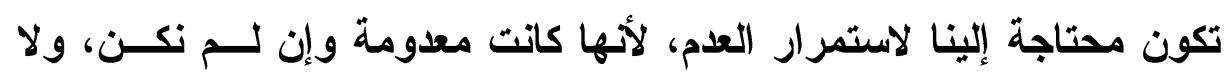
يجوز أن تكون محتاجة إلينا لاستمرار الوجود، لأننا نخرج عن كوننا قادرين

$$
\text { (') (المغتى جـ/^/ وما بعدها. }
$$

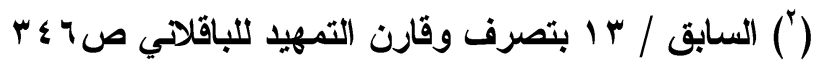


وهى مستمرة الوجود، وبيطلان هذين الأمرين لم يبـث إلا أن تكــون هـــه

التصرفات محتاجة إلينا لتجدد الوجود على ما نقوله('). استحالة مقدور بين قادرين : انظلاقا مما قرره المعتزلة في الفقرة السابقة من أن فعل العبد حـادث مـن جهته، وأن جهة احتياج الفعل إلى الفاعل هي جهة الحدوث، يقرر المعتزلـة بناء على ذلك استحالة وقوع مقدور بين قادرين، وذلك لأن الحــدوث الـــى يتعلق بالقادر هو من الصفات التي لا تقبل التزايد(؟) وتوضيحا للطريق الثانية:

تعرف الطريقة الثانية بطريقة الأمر والنهى، وهى طريقة المتقدمين من رجال المعتزلة، والاستدلال في هذه الطريقة يقوم على القول بأن العلم بحسن الأمر والنهى يتوقف على حصول العلم بتعلق تصرف العباد بهم ووقوعه حسـب قصودهم ودواعيهم يقول عبد الجبار "فأما الاستدلال على أن تصرف العبـــ فعله بالأم والمدح وحسن الأمر والنهى، فقد اعتمد عليه شيخنا أبـو علــى رحمه الله في كتبه وغيره من الشيوخ المتقدمين، وذكره شيخنا أبو هاشـــ رحمه الله أيضاً"(").

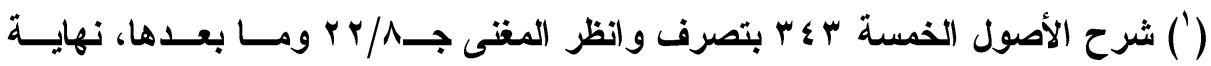

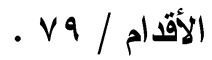

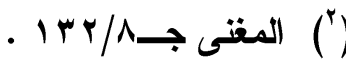

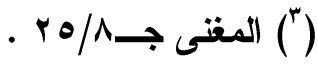


وكلام المعتزلة هنا - امتداد لكلامهم في الحسن والقبح، يقرر ذلــك الإمــام الألوسي قائلاً "إن أفعال العباد لو كاتت مخلوقة لله تعالى، لما نعاها علـيههم، ولا عاقبهم بها، ولا قامت حجة الله تعالى عليهم، ... وإن أسندوا الملازمــة وكذلك يفعلون إلى قاعدة التحسين والتقبيح، وقالوا معاقبة الإسسان مثلاً بفعل

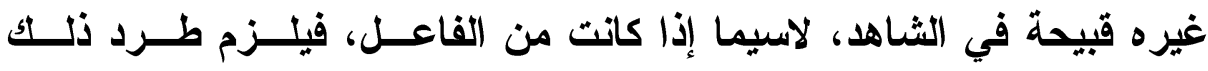

غائبًاً (1) ثانياً : الأدلة السمعية : المعتزلة لا يعولون كثيراً على الأدلة السمعية لإثبات أن العبد هــو المحســ لفعله، ذلك أنهم يرون أن الاستدلال بالسمع على هذه المسألة كأنه متعـــر، وذلك لأن صحة السمع إنما تتوقف على إثبات أن الله تعالى عــدل لا يظلــم، حكيم لا يعبث، وما لم يتوفر لنا علم بهذه الأمور لا يمكنتا الاستدلال بالقرآن على شيء من ذلك (). وليس معنى هذا الكلام أن المعتزلة لم يستخدموا الأدلة السمعية غاية الأمسـر أنهم إنما يوردون الأدلة الســمعية فـي هـــا الصــدد، للاســتئناس بهــا، والاستشهاد على أن القرآن قد دل على ما دل عليه العقل، يقول القاضي عبد

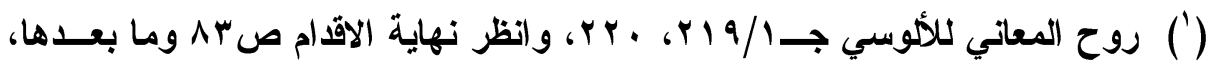

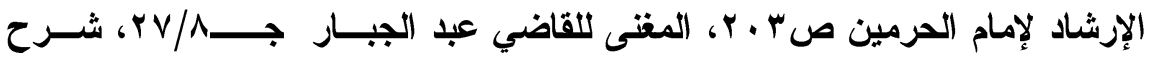
الأصول الخمسة له أيضا صبَrr.

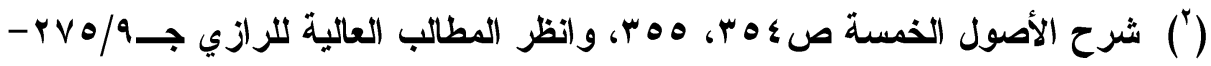
FV 
$\Lambda \varepsilon$.

الجبار مبينا أنه احتج بآيات من القرآن على أنه تعالى لا يجــوز أن يكــون

خالقاً لأفعال العباد، وذلك لم يورده على طريقة الاستـلال والاحتجــاج، فـإن الاستدلال بالسمع على هذه المسألة متعذر، وإنما أوردها على أن أدلة الكتاب مواققة لأدلة العقل ومقررة له ('). ومن الآيات التي يستدل بها المعتزلة الآيات التــي يـأمر الله فيهــا عبــاده بالطاعة، وينهاهم عن المعصية ويقولون لو لم يكن الإنسان محدثاً لفعله، لما

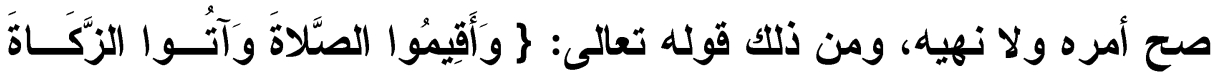

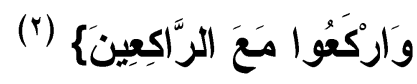

(') شرح الأصول الخمسة ص ع ه r، هـ ب باختصار

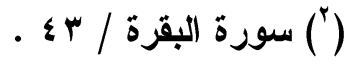


المبحث الثالث : المسألة في فكر الأثشاعرة والماتريدية:

أولاً : قول الأثشاعرة والماتريدية على وجه العموم :

نظر الأثاعرة والماتريدية إلى مسألة أفعال العباد نظرة تتسم بدقة المأخذ،

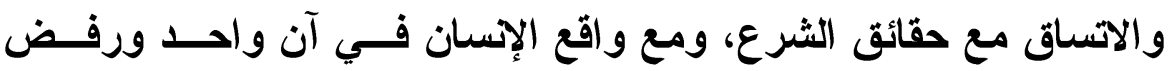
الأثشاعرة والماتريدية قول كل من الجبرية الجهمية، والمعتزلة وخرجـوا بقول متوسط بين هذين الطرفين، فقالو الا جبر ولا تفويض ولكن قــالوا بالكسب، وعبروا عنه بأنه أمر بين أمرين. انظر إلى الغزالي وهو يقرر توسط الأثشاعرة والماتريديـة بـين هـــين الطرفين، قائلاً: فانظر الآن إلى أهل السنة كيف وفقوا للسداد، ورشــحوا للاقتصاد في الاعتقاد فقالوا - القول بالجبر محال باطل، والقول بالاختراع اقتحام هائل، وإنما الحق إثبات القدرتين على فعل واحد، والقول بمقـدور منسوب إلى قادرين، فلا يبقى إلا استبعاد توارد القدرتين على فعل واحد،

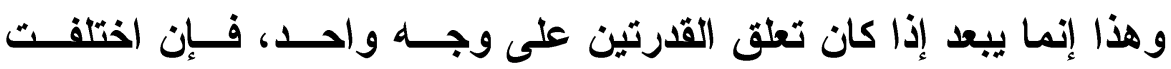
القدرتان، واختلف وجه تعقلهما، فتوارد القدرتين على شيء واحد غيـر

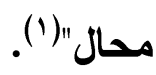
ويقرر الغزالي في موضع آخر أنه إذا بطل الطرفان - الجبر والقدر - لـــم يبق إلا الاقتصاد في الاعتقاد، وهو أنها - حركة العبد وأفعاله - مقــدورة

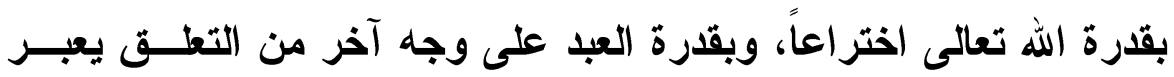


عنه بالاكتساب، وليس من ضرورة تعلــق القــدرة بالمقــدور أن يكـون

بالاختراع فقط (').

إذن - فمذهب الأثاعرة والماتريدية ق قائم على تحقيق الأفعال للعباد، لأنهم

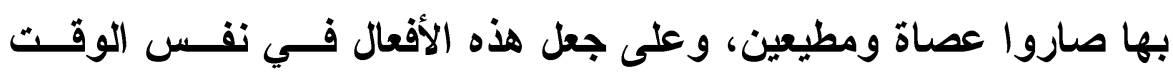
مخلوقة لله تعالى، وطبقاً لذلك رأى الأشاعرة والماتريدية أن بإثبات الأفعال للعباد يتحقق العدل وينتفى الظلم، وبإثبات أن هـــه الأفعــال مخلوقــة لله تعالى يتحقق ما وصف الله تعالى بـه نفسه مــن أنـــه ســبحانه وتعــالى:

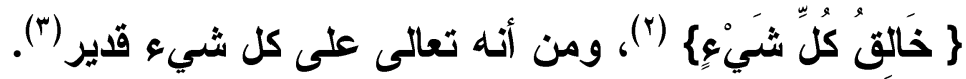
فقعل العبد على قول الأثاعرة والماتريدية له جهتان، جهة اختراع وخلق وإيجاد، وجهة اكتساب، والفعل ينسب إلى القـــرة الإلهيــة مـن جهــة اختراعه، وإلى قدرة العبد من حيث اكتسابه، فلم يــأت قــول الأثـــاعرة والماتريدية بالكسب من فراغ، وإنما هو حاصل نظرهم في ذينك الأمسـرين الأين أثرنا إليهما، وهما عموم القدرة الإهية، والتي من خواصها الخلق والاختراع والإيجاد والإحداث، وأن للعبد فعلاً أمر به ونهى عنه فتحصـل

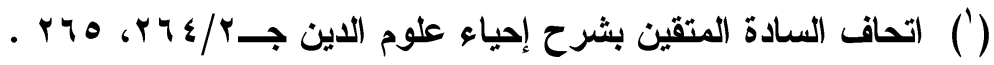

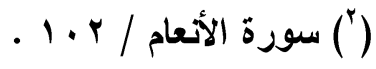

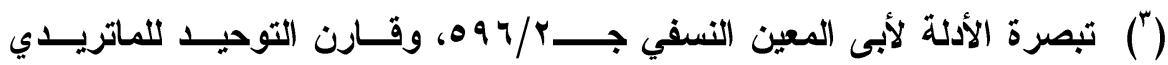
صq9r وما بعدها. 
من ذلك أن الله تعالى خالق للفعل مخترع له، وأن العبـــ مكتســب لهـــا

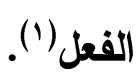

ويؤكد محققوا الأثاعرة والماتريدية، أن القول بأن للعبد في فعله الكسب فقط، وأن الله تعالى هو الخالق لفعل العبد كما هو الخالق للعبد نفسه، هو ضرورة ألجأ إليها التقابل بين الأمرين السابقين المشــار إليهمــا، يقــول السعد: لما ثبت بالبرهان أن الخالقى هو الله تعالى، وبالضرورة أن لقــدرة العبد وإرادته مدخلاً في بعض الأفعال، كمركة البطش دون البعض كحركة الارتعاث احتجنا في التفصي عن هذا المضيق إلى القول بأن الله تعـالى خالق كل شيء و العبد كاسب"(r). هذا وقد ظهر القول بالكسب في كلام الأشاعرة والماتريدية منذ زمن مبكر، فقد عبر الإمام أبو حنيفة رحمه الله تعالى عن الفعل الإنساني، بأنه خلــق الله تعالى وكسب للعباد، حيث يقول في الفقه الأكبر "وجميع أفعال العبـاد من الحركة والسكون، كسبهم على الحقيقة، والله خالقها"(")

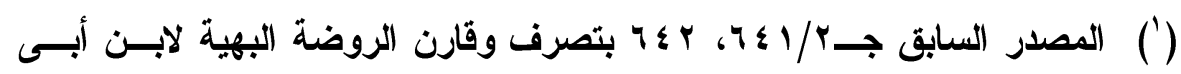
عزبة صبr • ب وما بعدها.

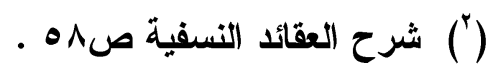

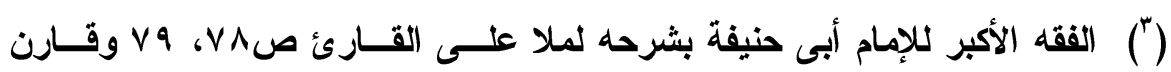

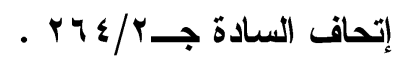


ثم توارث الأثاعرة والماتريدية القول بالكسب، فيما بعد، وكان محل اتفاق

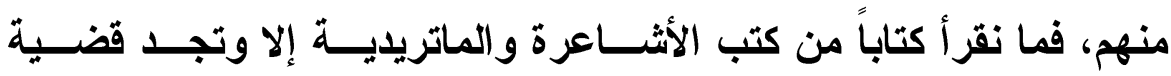
الكسب، أو القول بالكسب من بين القضايا البارزة فيه. وقد آثر الأشاعرة والماتريلية أن يعبروا عن الفعل الإسـاني بأنه كسـب تيمنا بكتاب الله تعالى فإنه وجد إطلاق ذلك على أعمال العباد في القرآن (1) وتعبير الأثـاعرة والماتريدية عن تلأك العلاقة بين الإسـان وفعلــه، بأنهــــا كسب إنما جاء بعد رفضهم لقول من يجرد الإنسان من أي قرة أو اختيار كالجبرية، وقول من يسند الفعل إلى العبد استقلالاً كالمعتزلة، مع اعتراف أئمة الأثـاعرة والماتريدية أنفسهم بصعوبة المسألة في نفسها، وصعوبة أن يقال فيها قولاً فاصلاً يحدد نصيب القدرة الإههية، والقدرة الإساتية في الفعل. فاكتفى الأشـاعرة والماتريدية بعد قيام الأدلة على بطلان قول كـلـ مـن الجبرية والمعتزلة - اكتفوا بأن يقال بأن قدرة الإسـان تتعلق بفعله بوجه ما من التعلق يعبر عنه بالكسب، وبه يصح التكليف، ويتأتى المدح والأم، وما يتبعهما من ثواب وعقاب، أما تحديد كنه هذا التعلق أو كيفيته فهــو غير لازم. يقول السعد: - وتحقيقه - الكسب - أن صرف العبد قدرته وإرادته إلـى الفعل كسب، وإيجاد الله تعالى الفعل عقيب ذلك خلق، والمقـدور الواحـــ

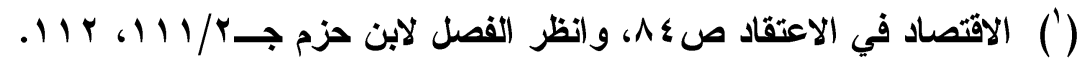


داخل تحت قرتين لكن بجهتين مختلفتين، فالفعل مقدور لله بجهة الإيجاد، ومقدور للعبد بجهة الكسب، وهذا القدر من المعنى ضروري، وإن لم نقدر على أزيد من ذلك في تلخيص العبارة المفصحة عن تحقيق كون فعل العبد بخلق الله تعالى وإيجاده، مع ما فيه للعبد من القدرة والاختيار ('.) ويشير ابن الهمام متضامناً مع السعد في هذا الملحظ أو المأخذ قائلاً: قام البرهان على وجوب كون كل موجود صادراً عن قدرته تعالى ابتداء بــلا واسطة، وعلى وجوب تعلق قرة العبد بأفعاله الاختيارية للعلم الضروري بالتقرقة بين حركتيه، صاعداً وساقطاً، فنقول بهما، وإن لم نعلــم حقيقــة وكيفية هذا التعلق فإنه غير لازم"(؟). جواز دخول مقدور واحد تحت قدرة قادرين: على خلاف من المعتزلة لم يدفع الأشـاعرة والماتريدية القول بأن لقـــرة العبد تعلق بفعله إلى القول بإخراج الفعل الإنساني الاختياري عن قدرة الله

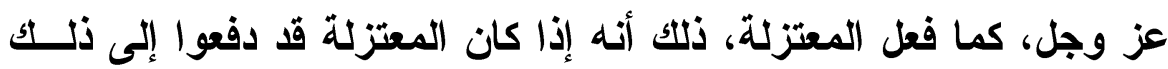
بسبب قولهم إن قدرة العبد تتعلق بفعله على جهة الإحداث، فامتنع عندهم - أو استحال دخول مقدور واحد تحت قــدرة قــادرين، فــإن الأثـــاعرة

(') شرح العقائد النسفية للإمام السعد ط مكتبة الكليات الأزهرية م ـ ـ اهـ، ص1ه،

المسايرة في علم الكلام لابن الهمام ص اه، به، وانظر نشر الطو الع لســاجقلى

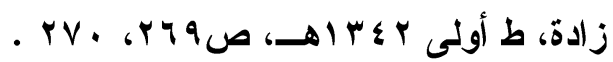




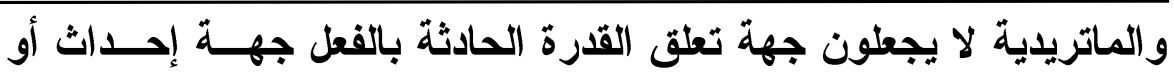

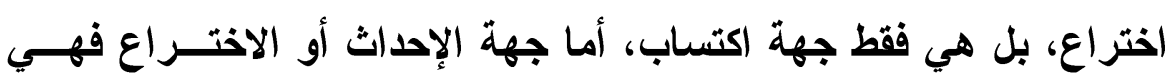
خاصة بالقدرة الإهية، وهكذا لما اختلفت جهتا التعلق أجساز الأثــاعرة و الماتريدية أن يلخل مقدور واحد هو فعل العبد تحت قدرة الله عز وجـل القديمة، وقدرة العبد الحادثة، فتتعلق به قدرة الله تعسالى خلقـاً وإحـــاثاً

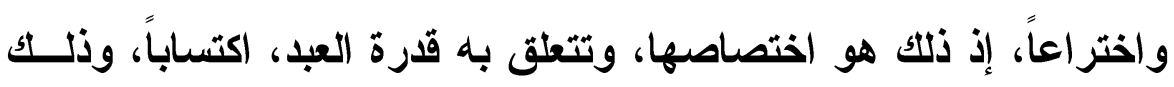
هو ما يناسبها. يقول أبو المعين النسفي "وبالوقوف على ما بينا من استحالة ثبوت قــدرة الاختراع للعبد، ودليل ثبوت الفعل والقدرة له، يعرف جواز دخول مقــدور

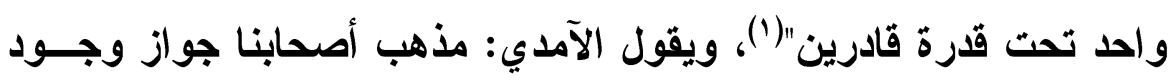
مقدور بين قادرين، خالق ومكتسب، وامتناع ذلك بين قادرين خـالقين أو وهي

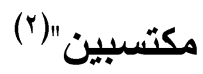
ولقد احتج الأثشاعرة والماتريدية على قولهم بجواز دخول مقــدور واحـــ تحت قدرة قادرين خلقاً واكتساباً بأدلة كثيرة (").

$$
\begin{aligned}
& \text { (') تبصرة الأدلة للنسفي جـr/r ؟ ؟ . }
\end{aligned}
$$

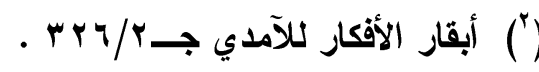

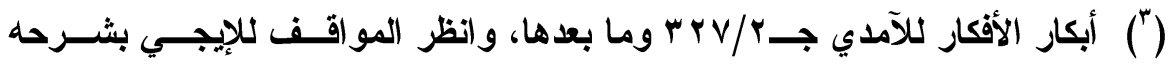

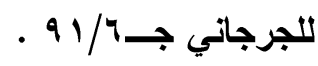


ولقد قصد الأشاعرة والماتريدية بإثباتهم أن فعل العبد داخل تحت قدرة الله عز وجل بخلقه، وتحت قدرة العبد باكتسابه، إبقاء عموم تعلق قـدرة الله عز وجل بكل مقدور، لا فرق في ذلك بين أن لا تتعلق به قدرة العبـــ أو تتعلق به، فليس تعلق قدرة العبد بالفعل على سبيل الكسب بمانع من تعلق قدرة الله عز وجل به على سبيل الخلق، فينتج من هذا كله عند الأشاعرة والماتريدية أن لا مقدور إلا والله عز وجل قادر عليه، أو كما يقول الإمام الأشعرى "وقال أهل الحق لا مقدور إلا والله سبحانه عليه قادر، كما أنه لا معلوم إلا والله به عالم "(1). كما أن قول الأشناعرة والماتريدية ، بأن فعل العبد متعلق بقدرة الله تعالى من حيث خلقه وبقدرة العبد من حيث اكتسابه، إنما هو حصيلة محافظتهم على كلية خالق كل شيء التي وصف الله تعالى بها نفسه في قوله تعالى:

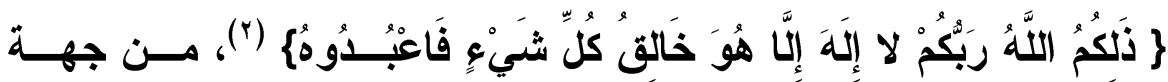
وإثباتهم للعبد قدرة محدثة لها تعلى بفعله من جهة ثانية يقــول الآمـــي موضحاً ذلك: " ثبت بما قدمناه في امتناع خالق غير الله تعالى - وجــوب تعلق قدرة الرب تعالى بكل ممكن، وثبت بما قدمناه فــي إثبــات القــــرة 
الحادثة وجوب تعقها بمقدورها، ويلزم من الأمرين أن يكون مقدور العبد

اكتساباً مقدوراً للرب خلقاً" (1).

إذن فلا مكان للقول باستحالة مقدور بين قــادرين فــ نظــر الأثــــاعرة و الماتريدية، بل إن القول بالاستحالة هو ورطة على حد تعبير ابن المنير الذى يقول "وأما استحالة المقدور بين قادرين فإنها ورطة، وإنما يستاق يدفع- إليها القدرية الذين يعتقدون أن ما تعلقت به قدرة العبد استحال أن تتعلق به قدرة الرب، إذ قدرة العبد خالقة فيستغنى بها عن قــــة خـالق آخر" (ن) و إذا جاز مقدور بين قادرين على ما يقول الأثشاعرة و الماتريدية، وكاتسـت

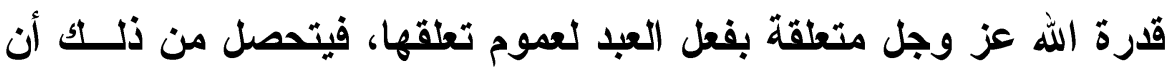
كل فعل صدر من العبد اختياراً فله اعتباران، كما يقول بن المنير: - إن نظرت إلى وجوده وحدوثه وما هو عليه من وجـوه التخصـيص، فانسب ذلك إلى قدرة الله وحده وإرادته لا شريك له. - وإن نظرت إلى تميزه عن القسر الضروري، فانسبه من هذه الجهة إلى العبد، وهى النسبة المعبر عنها شرعاً بالكسب(").

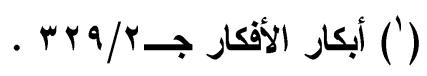

(") الاتصاف لابن المنير بهــامش الكثــاف للزمخثــري، ط دار الفكـر بـــون،

$$
\text { rrT/l } \rightarrow
$$

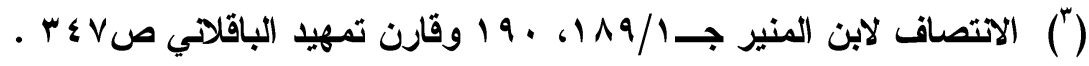


وبالجملة فمذهب الأشاعرة والماتريدية في الإنســاتيات، قـائم علــى أن الخالق لها والمحدث لها هو الله سبحانه وتعالى، وأن للعباد فيها الكسـب فقط، وأن هنالك فرقاً بين نوعين من أفعال الإنسان، فهنالك فعل اضطراري يخلقه الله عز وجل، من غير اقتران قدرة العبد وإرادته به، فيكون صــفة للعبد لا فعلاً له، وذلك كحركة المرتعش، وهناك فعل آخر اختياري يخلقــهـ الله عز وجل ويوجده مقارناً لقدرة العبد، فيوصف بأنه فعل للعبد وكسـب

ولقد تواردت أقوال أئمة الأشاعرة والماتريدية مؤكدة هذا المذهب، يقول الباقلاتي "اعلم أن مذهب أهل السنة و الجماعة أن الله تعالى هــو الخــالق وحده، لا يجوز أن يكون خالق سواه، وحركات الحيوانات قيلها وكثيرها، حسنها وقبيحها، خلق له تعالى، لا خالق لها غيره، فهـي منــهـ خلــق،

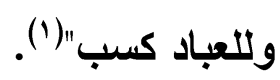

ولقد توسط الأشـاعرة والماتريدية بقولهم هذا، بين طرفي الجبر والقــدر، فتجنبوا ما لزم هذين الطرفين من تفريط في جانب الجبرية وإفــر اط فـي جاتب المعتزلة، وهذا القدر من القول - أن الله تعالى خالق لفعل الإسان وللإنسان فيه الكسب، محل اتفاق وإجماع من الأشاعرة والماتريدية، أمسـا توضيح المراد بالكسب، فقد وقع فيه بعض الاختلاف 
أقو ال الأثداعرة والماتريدية في بيان المراد بالكسب :

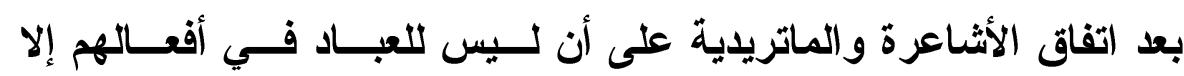
الكسب، اختلفوا في بيان المراد بهذا الكسب، وكان اختلافهم يدور حول ما

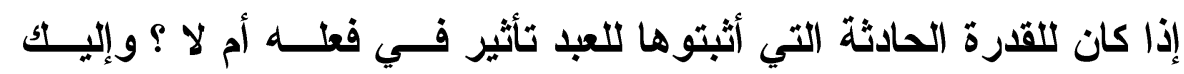
بعض أقو الهم في ذلكك: أولاً: قول الإمام الأثشعري: أثثت الإمام الأثـــعري للإنســان فــي فعـــهـ

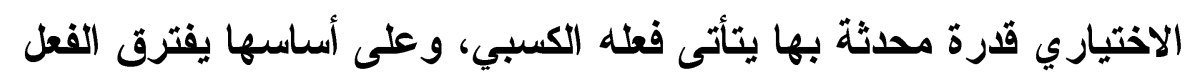
الكسبي عن الفعل الاضطراري، إلا أن هذه القدرة الحادثة لا يرقى أثرهـا

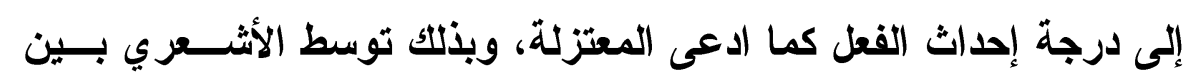
قول الجبرية التي جردت الإسسان عن أي قدرة، وبين قول المعتزلة التــي

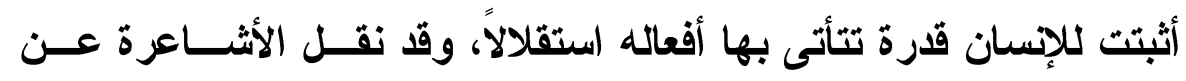
شيخهم أن مراده بالكسب أن القدرة الحادثة تكون مقارنة للمقدور بها من غير أن تؤثر في إحداثه إذ التأثير بالإحاث من خصائص القدرة القديمسة

الثابتة لله عز وجل (1) ثانياً: قول الباقلاني: تعدى الإمام الباقلاني كما نسبت إليه كتب علم الكلام

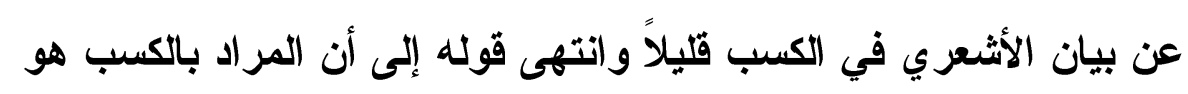

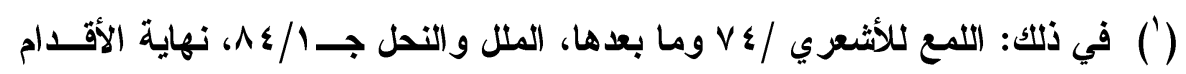

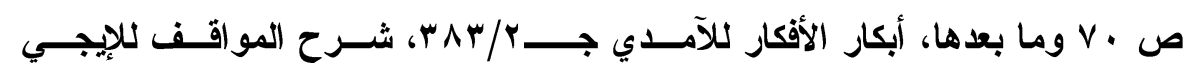

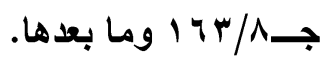


أن القدرة الحادثة التي هي للعبد تؤثر في صفة الفعل أعنى كونه طاعة أو معصية، أما ذات الفعل، فإنها من أثار قدرة الله عز وجل، وقد تبنى الإمام الثهرستاني هذا القول في الكسب ودافع عنه، وحاول إثبات أن الباقلاني بقوله هذا لم يخالف ما أجمع عليه الأثشاعرة والماتريدية من أن الله تعالى خالق كل شيء، ذلك أنه - أبي الباقلاني- جعل تأثثر القدرة الحادثة فــي

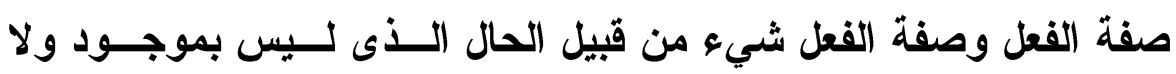

معدوم) (1) ثالثاً : قول الإسفر ايينى: ممن حاول توضيح المر اد بالكسب، الإمسام أبسو

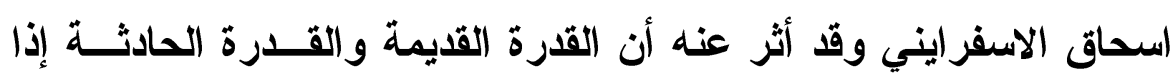
تعلقتا بمقدور واحد، وقع المقدور بهما كأنه فعل العبد وقـع بإعانــة الله، فهذا هو الكسب، لأنه قد أثثر عن الإسفرايني أنه قال الكسب هـــ الفعـل الو اقع بالمعين، ولكن ما محل تأثير القدرة الحادثة في الفعل، حاول الإمام

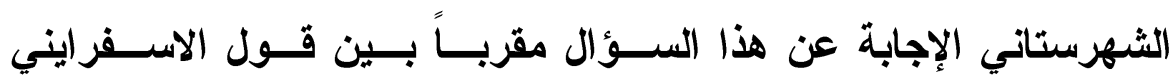

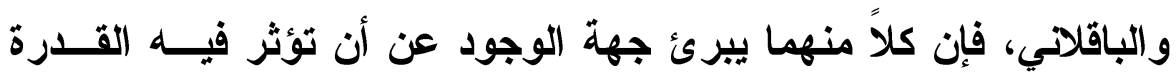

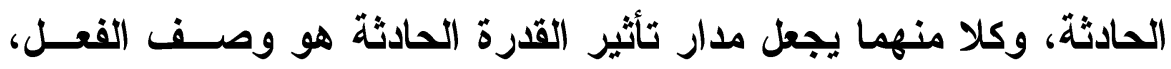
غير أن الباقلاني يجعل هذا التأثير في حال الفعل لأنه يثبت الحسـال، أمس

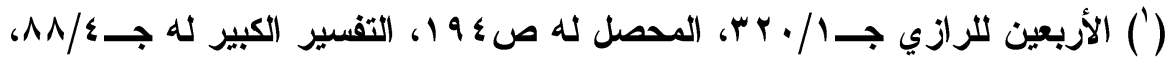

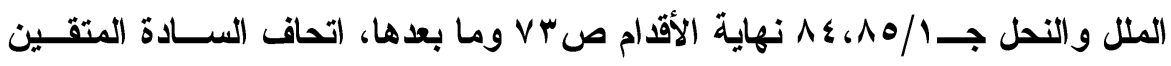
بشرح إحياء علوم الدين جـ/r/r T وما بعدها. 


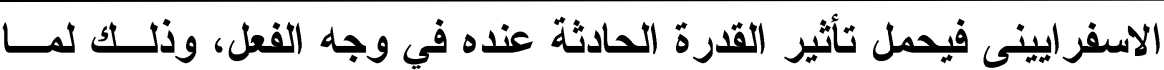

اشتهر عنه من إنكاره للحال(').

رابعاً : قول إمام الحرمين : تبنى إمام الحرمين في أول حياته مـا كسـان يقول به الأثعري من أن القدرة الحادثة لا تؤثثر في مقدورها أصسلِا، وأن كل شيء إنما حدث بقدرة الله تعالى من غير فرق بين ما تتعلق به قـــدرة العبد، وما لا تتعلق به، ثم ذهب في آخر حياته، وفـى كتابــه المســى بالعقيدة النظامية - إلى خلاف ما تبناه في أول حياته العلميـة، وحاصـل رأيه في هذه المرحلة وفيما يخص الإنسانيات، هو أن القدرة الحادثة تؤثر في وجود الفعل الأى تتعلق به غير أنها غير مستقلة بهذا التأثير وإنمسا تستند إلى سبب آخر تكون نسبتها إليه كنسبة الفعل إليها وهكنا إلـى أن تنتهى الأسباب إلى الله عز وجل الخالق المبدع المستقل بإبداعه من غير احتياج إلى سبب - وقد اهتم إمام الحرمين حتى وهو في هذه المرحلة أن

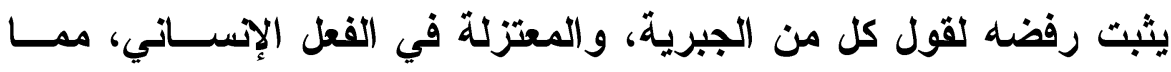
يجعلنا نجزم بأن الإمام لم يتفق مع المعتزلة في قولهم في الإسانيات كما قد يدعى البعض().

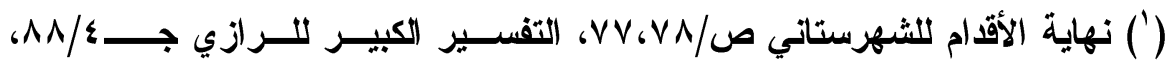

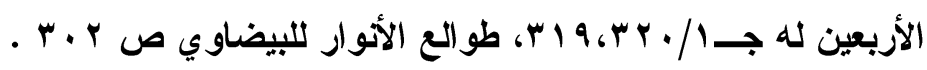

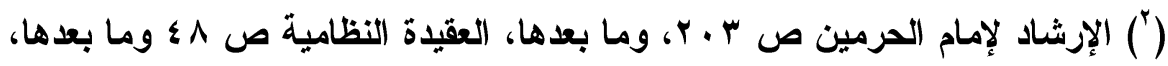

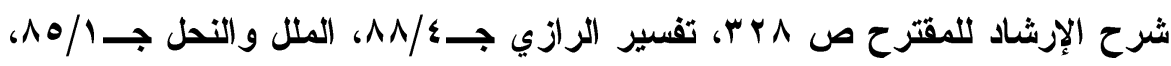

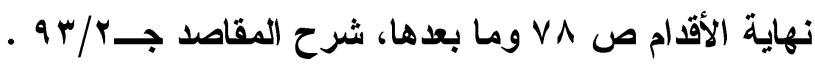


خامساً : موقف متأخري الأشاعرة : مما نسب إلى الباقلاني والإسفرايني

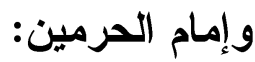
نلمس اتجاهات ثلاثة في الفكر الأشعري تجاه هذه الأقوال التي نسبت إلى

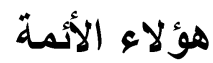
الأول: استنكار صدور مثل هذه الأقوال عن هؤلاء الأثمة والتشــكـ فـي صحتها، أو محاولة حملها على أنها صدرت منهم علـى طريقــة الجــل و المناظرة. ثانياً : حاصله النقد والتفنيد لهذه الأقو ال. الثالث: محاولة التقريب بين هذه الأقو ال وبين ما أجمع عليــه الأشــاعرة ومحاولة التقليل من المخالفة بل محاولة إثبات أن هذه الأقوال لم تخــرج عما قاله الإمام الأشعري في الكسب وممن ذهب إلى الاتجاه الأول - الإمام السنوسي(')، وممن ذهب إلى الاتجاه الثاني الإمام الآمدي(؟)، وممن ذهب إلى الاتجاه الثالث الإمام الثهرستاني (זّ) تجاه قول كـلـ مــن البــاقلاني والإسفر ايني (๕) والإمام السعد تجاه قول الإسفر اييني(ه)

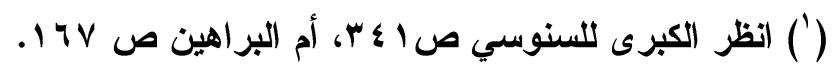

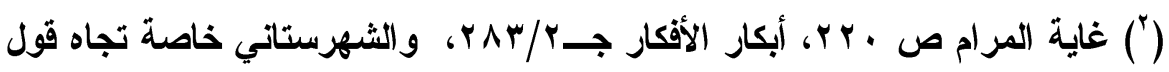
إمام الحرمين، نهاية الأقدام صar.V9.Vr.Vr.

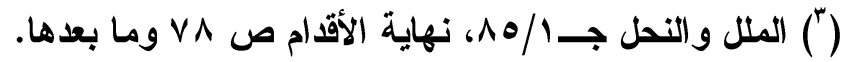

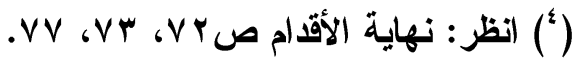

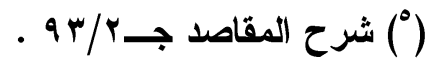




$$
\text { الكسب عند الإمام الكور اني }
$$

ونرى الجها الأكبر في هذا الاتجاه الثالث فيما قام به الإمام الكوراني الذى يرى أن حاصل قول الأشعري في الكسب إنما هو نفى الاسـتقلال الـــى ادعاه المعتزلة، ولا يمنع نفي الاستقلال من إثبات التأثير للقدرة الحادثــة في مقدرها تأثيراً مرتبطاً بإذن الله تعالى، وقد اعتمد الإمام الكوراني في فهمه هذا على نصوص من كلام الأثعري وخاصة من كتابه الإبانة، وبناء على هذا الفهم أنزل الكور اني قول الإسفر ايني على ذلك، وبنـاء على ذلــــ الفهم جعل الكوراني القول الأخير لإمام الحرمين تحقيقاً لقول الأثنعري في الكسب.

وهذا الجهد من الإمام الكوراني لله اعتباره وقيمته ذلك أنه يجمــع هـذه الأقوال التي صدرت من هؤلاء الأيمة في الكسب فيجعلها جميعاً تدور في إطار واحد هو نفى الجبر الخالص ونفي الاستقلال المطلق('). سادساً: توضيح المراد بالكسب عند الماتريدية يقــول صــاحب الروضــة البهية، الكسب هو صرف القدرة إلى أحد المقــدورين وهــو - أي هـــا الصرف - غير مخلوق لأن جميع ما يتوقف عليه فعـل الجـوارح مسن

(') في ذللك كتاب مستلك السداد إلى مسألة خلق أفعال العباد للإمام الكوراني مخطوط

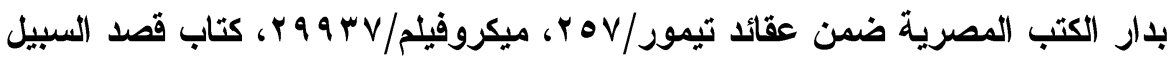

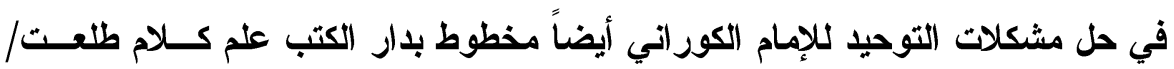

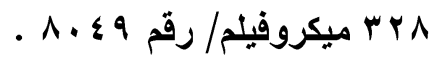


الحركات وكذا التروك، هي أفعال النفس من الميل والداعيـة والاختيـار بخلق الله تعالى، لا تأثير لقدرة العبد فيه، و إنما محل قدرته عزمه عقيـبـ خلق الله تعالى هذه الأمور في باطظه عزماً مصمماً بلا تــردد، وتوجهـاً

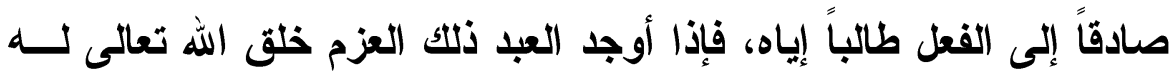

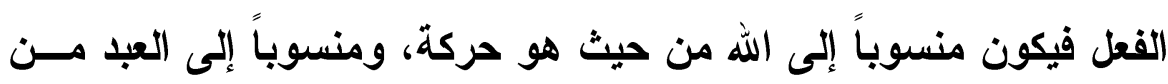

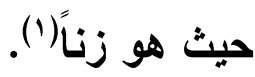

وتوضيحاً لهذا الكلام يقول الإمام البياضي - أصل الفعل بقدرة الله تعالى، والاتصاف بكونه طاعة أو معصية بقدرة العبد، وهـو مــذهب جمهـور

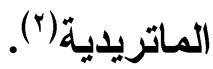
وإذا أمعنا النظر في قول الماتريدية لر أيناه يئؤل إلى قول البـاقلاني فــي

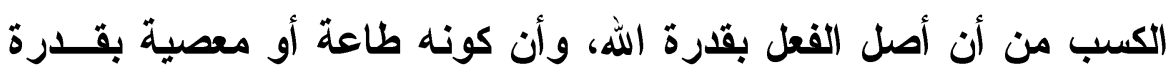

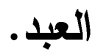

وحاصل القول : أن الذى يجمع الأثداعرة والماتريدية هـو رفـض قــول الجبرية و المعتزلة، والإجماع على أن الله تعالى خالقى كل شيء بما فــي ذلك الفعل الإساني، وأن للإنسان قدرة محدثة على أفعاله الاختيارية ولها تعلق بهذه الأفعال وهذا التعلق هو ما يعبر عنه بالكسب، وعلـى أســاس

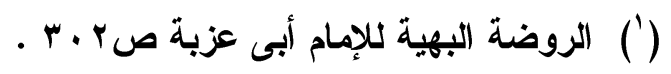

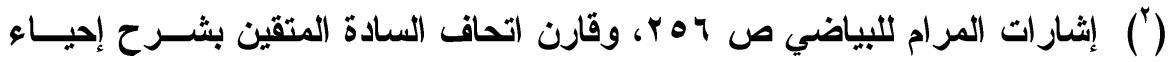

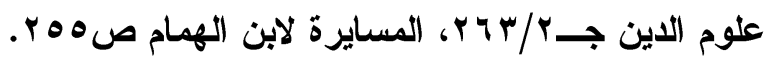


القول بالكسب يصح التكليف ويتأتى الثواب والعقاب، أما تعديد أثر هـــه القدرة الحادثة في الفعل الإسـاني فهو مما اختلف الأثشاعرة و الماتريديــة في توضيحه.

منهج الاستدلال على الفعل الإساني عند الأثاعرة والماتريدية : سوف نعمد إلى أهم أدلة الأثاعرة والماتريدية في هذا الصدد، مع ذكر ما قـ يكون للخصوم عليها مـن الاعتر اضــات، وكيـف تتـــاول الأثـــاعرة و الماتريدية هذه الاعتراضات بالتفنيا والإبطال.

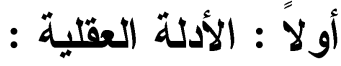

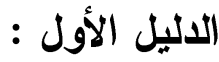

أن فعل العبد ممكن، فتشمله قدرة الله تعالى، يعبر الإمام السعد عن هــــ الاليل بقوله "فعل العبد ممكن، وكل ممكن مقدور لله تعالى، لما مــر فــي بحث الصفات، ففعل العبد مقدور لله تعالى، فلو كان مقدوراً للعبـــ أيضــاً

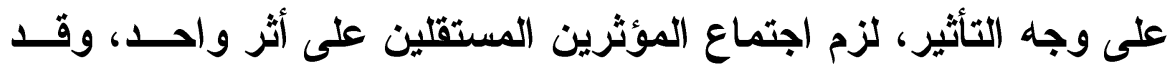
بين امتناعه في بحث العلل. فإن قيل اللازم من شمول قدرته تعالى، كون فعل العبد مقدوراً له، بمعنى

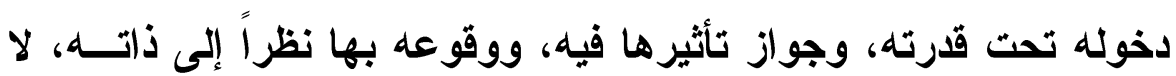
بمعنى أنه واقع بها ليلزم المحال. 
قلنا جواز وقوعه بها مع وقوعه بقدرة العبد يستلزم جواز المحال وهـو

محال. (1) الاليل الثاني :

يقول الأشـاعرة والماتريدية إن العبد لو كان خالقاً لفعـــه، لكــان عالمــاً بتفاصيل ذلك الفعل، ضرورة أن إيجاد الثيء بالقدرة والاختيار لا يكـون إلا كذلك، أي عن علم، واللازم وهو علم العبد بتفاصيل فعله باطل، فبطــلـل

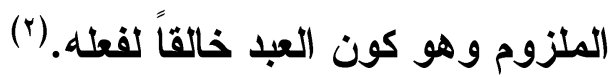
ويضيف الأشاعرة والماتريدية هنا بأن العبد لو كان يخلق فعله، في حين أنه غير عالم بتفاصيله لأدى ذلك إلى إخراج الإتقان والإحكام فـــي الفعـل عن أن يكونا دالين على علم المخترع، وفى ذللك ما فيه من نقض للالالة

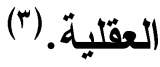

هذا وهناتك كثير من الأدلة العقلية التي يستدل بها الأثثاعرة والماتريديــة،

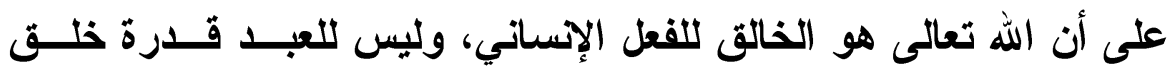

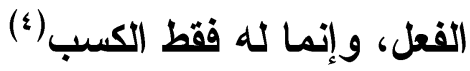

(') شرح المقاصد للسعد جـ/ ؟ 9، وانظر أصول الدين للبزدوى صه ـ 1، الأربعين

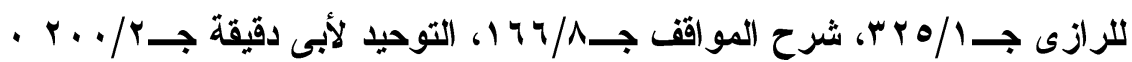
(") هذا الاليل في حاثية السباعي على خريدة الدردير ص^^^، شرح العقائد النسفية ص .00. (") الإرشاد لإمام العرمين ص. 19 19، 191 بتصرف.

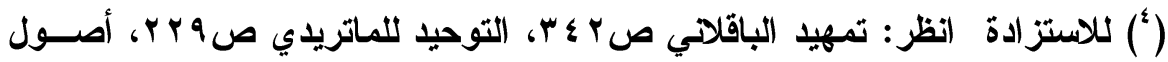

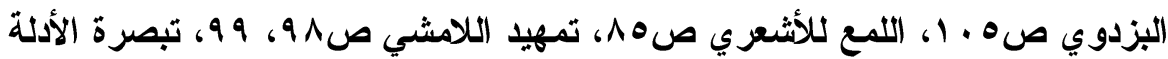

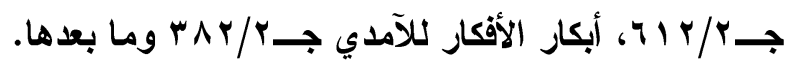


الأدلة السمعية للأشاعرة و الماتريدية على قولهم:

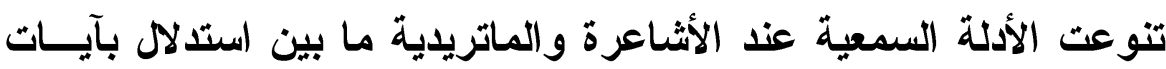
القرآن الكريم، وما بين استدلال بأحاديث النبي صلى الله عليه وسلم، وما بين إجماع سلف الأمة قبل ظهور البدع والخلافات فمن ذلك ما يلي:

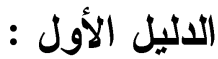

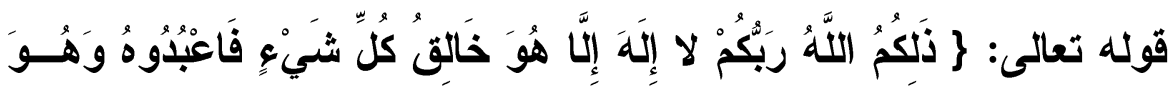

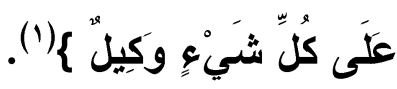
بين الأثاعرة والماتريدية أن وجه الاستدلال بهذه الآية على أن الله تعالى

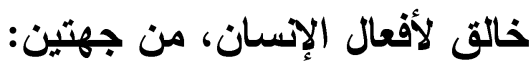

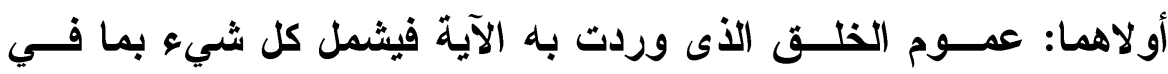
ذلك فعل الإنسان ثانيتهما: أنها وردت في مورد التمدح الله عز وجل، فلا يصــح اســثناء

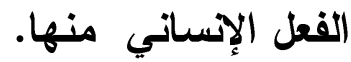
يوضح الباقلاني الجهة الأولى، قائلاً، إن أفعال العباد مخلوقة إجماعاً، وإن اختلفنا في خالقها، وفى هذه الآية قد أدخل الله في خلقه كل شيء مخلوق فذل أنه لا خالق لثيء مخلوق غيره سبحانه وتعالى (†).

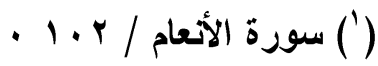

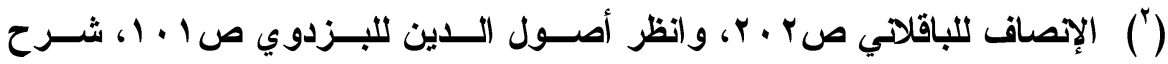

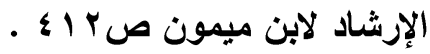


أما الجهة الأخرى، فيوضحها الإمام السعد بقوله : هذه الآية وردت فـي معرض التمدح للمولى سبحانه وتعالى، وبيان استحقاقه للعبادة، فلا يصح الحمل على أنه خالثق لبعض الأشياء كأفعال نفسه - كما يرى المعتزلة -

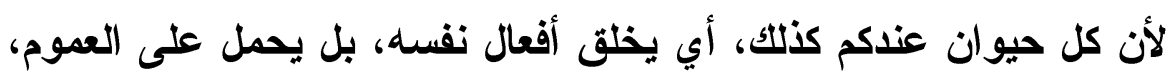
فيلخل فيه أعمال العباد ('). ويوضح إمام الحرمين هذين الأمرين، اللأين أفادتهما الآية، حتى اسـتـال

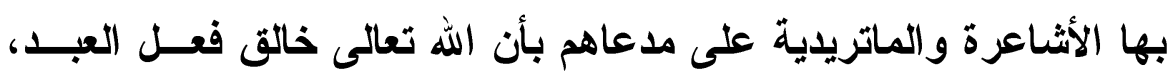
فيقول "الآية تقتضى تفرد الباري تعالى بخلق كل مخلوق، والاستدلال بها

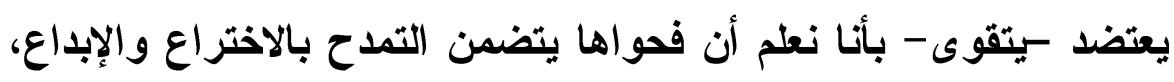

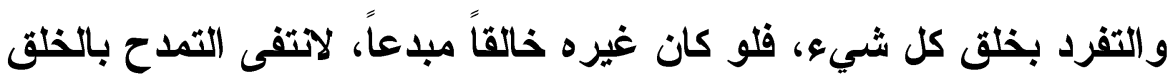

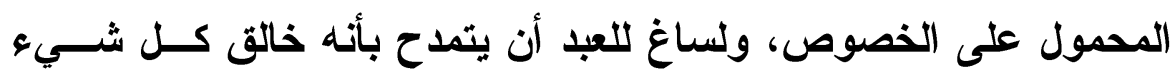

ومر اده أنه خالقى لبعض الأثشياء (ץ). الاعتر اض على الاستدلال بالآية:

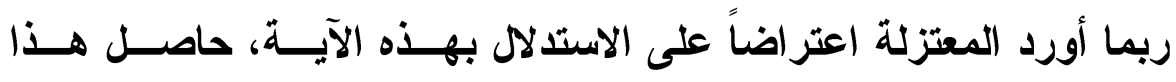
الاعتر اض، أن الآية وردت بصيغة العموم، وهذا العموم يحتــل تأويلــهـ وتخصيصه، وكل ظاهر متعرض لجهات الاحتمالات، لا يسوغ التمسك بــه

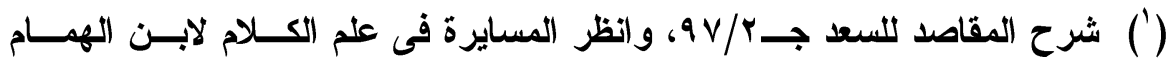
ص ب ؛ وما بعدها.

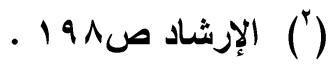


في القطعيات، وتوضيحاً - يقول المعتزلة هذه الآية مما يجب تخصيصــها لأمرين:

الأول: أنها خرجت مخرج التمدح، ولو أدخلنا أفعال الإنسان فيها، وقتنا إن الله تعالى هو الخالق لها لزال هذا التمدح، بل يثبت هنالك معنـى يوجـب الأم، فإن في أفعال الإسسان ما هو قبيح، وما هو افتراء على الله تعـالى، مما لا يصح أن يكون الله تعالى هو الخالق لها، وعندئذ نقول إنه تعـالى أراد بهذه الآية الخصوص وإن خرجت مخرج العموم("). الثاني: يقول المعتزلة مما يدعم كون هذه الآية خاصة، وإن وردت عامة أنها جاعت بلفظ الخلق لكل شيء، وذات الله تعالى شيء بلا خلاف بينـــا

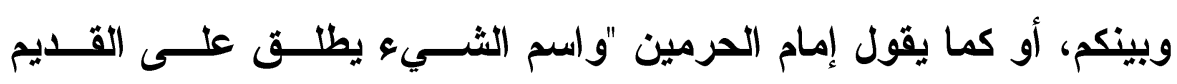

و الحادث"(r) (r) (ب)

ولم تكن ذاته تعالم داخلة تحت هذه الآية، لما في ذلك من زوال ما سيقت له الآية من إثبات التمدح، إلى ما يضاده، من إثبات التقيصــة الموجبـة للأم، إذن فلا يصح في نظر المعتزلة أن يستدل بهذه الآية على كــون الله

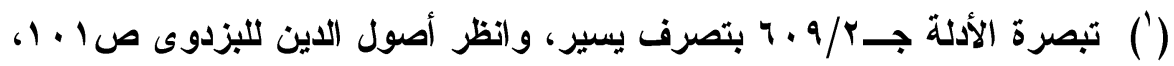

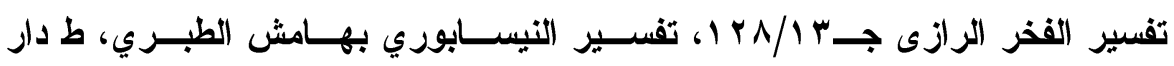

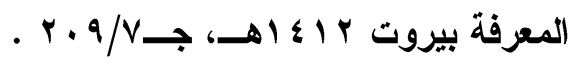

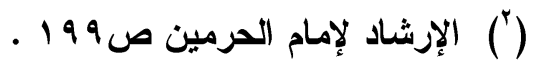


تعالى خالقاً لأفعال الإنسان إذ يتطرق إلى عمومها هذا التخصـيص مـن

هاتين الناحيتين (1).

رد الأشاعرة والماتريدية على هذه الاعتر اضات :

أولاً: التأكيد على أن الآية خرجت مخرج التمدح، ومعنى التمدح يحصـل بما يختص هو تعالى به، ولا يشاركه فيه غيره، ولو خص منه المتتــازع فيه - الإنسانيات - لزال معنى التمدح الأى وردث الآية مفيــدة لــه، إذ يصير معنى الآية إن الله تعالى خالق كل شيء هو فعله، أو خــالق كـلـ شيء ليس بفعل غيره، وهذا المعنى يساويه فيه كـلـل مــا لــه الأفعـال الاختيارية من إنسان وغيره، لأن كل هذه الأشياء عندكم يتأتى فيها أنهــا خالقة لكل شيء هو فعلها، أو ليس بفعل لغيرها، ولا تمدح الله تعالى بمــا يساويه فيه كل ما دب ودرج(؟). ثانياً: قول المعتزلة بأن الإنسانيات فيها القبائح، ولا يجوز أن يكـون الله تعالى خالقاً لها، وإلا لحقه وصف السفه سبحانه وتعالى عن ذلك، قياســاً منهم على فاعل ذلك في الثـاهد، فيرد الأثـاعرة والماتريدية علــى ذلــــ، بأنه يجب الفصل بين الشاهد والغائب في هذه المسألة، فليس كل ما قـبح

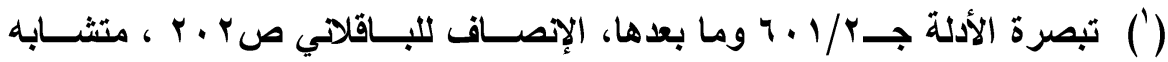
القرآن ص اهـץ-\{ ه ץ.

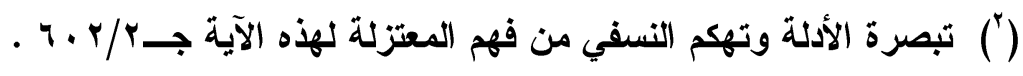


في الثاهد قبح مثله في الغائب، فهذا استمرار من المعتزلة على أصــلهم

الفاسد في التحسين والتقبيح. (1)

ثالثاً : أما محاولة المعتزلة إخراج الآية عن عمومهــا إلـى الخصــوص متمسكين في ذلك بأن ظاهر اللفظ يقتضى دخول ذات الله تعالى تحت هـــا العموم، فيجب أن تكون الآية مخصوصة، وإذا قبلت التخصيص على هـــا النحو، فلا مانع من أن يخصص منها كذلك الإنسانيات. فإن هذا الفهم خطأ في نظر الأشاعرة والماتريدية، بل هو على حد تعبيـر أبى المعين النسفى "جهل متفاحش"(؟) وذلك لأن التخصيص إنما هو خروج ما يوجب ظاهر اللفظ بقضية اللغة دخوله فيه، وليس التخصيص خــروج مالا يقتضى ظاهر اللفظ دخوله فيه، وبنـاء على ذلك نقــول، خــروج ذات الباري تعالى من هذا العموم ليس تخصيصاً، بل هي لم تكن داخلة أصــلاً حتى يكون خروجها تخصيصاً.

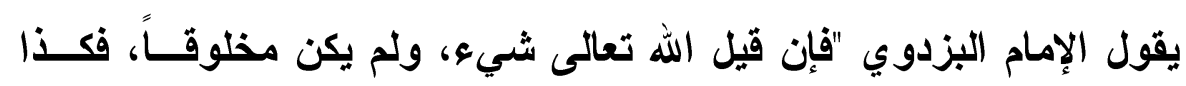
الأفعال لا يبعد أن تكون كذلك، وكذا صفات الله عندكم وأفعاله، فنقــول الله

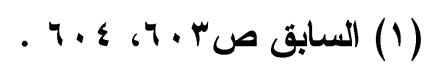

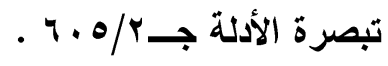


تعالى بأفعاله، وصفاته لا يـخل تحث هذا النص، - كما إذا قيـل، فــلان

ضارب كل حي، لا ياخل الضارب تحت ذلك الكلام من حيث اللغة (1) ويقول السعد مؤكداً أن ظاهر الآية يجب أن يحمل على العموم، فيدخل فيه أعمال العباد، ويخرج القديم -تعالى - بدليل العقل، والقطع بأن المــتكلم لا ياخل في عموم مثل أكرمت كل من دخل الارار(r) وإذا بطل كلام المعتزلة هنا تبقى الآية حجة للأشاعرة والماتريدية علـى قولهم في أفعال الإنسان.

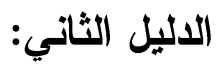

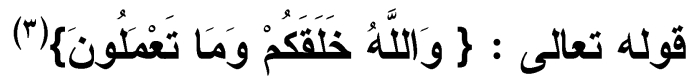
ونلاحظ هنا ترقى الأثاعرة والماتريدية في الاستدلال على كون الله تعالى

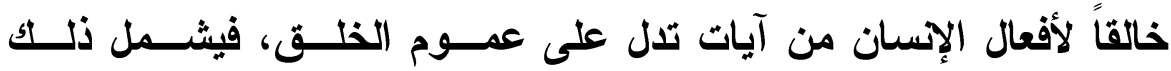
الإنسانيات، إلى آيات تلدل صراحة على أن العــل مخلــوق كمـــا العبــاد مخلوقون.

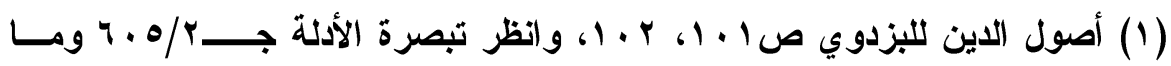

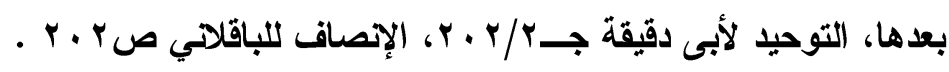

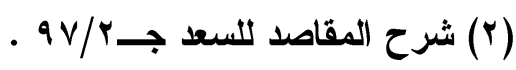

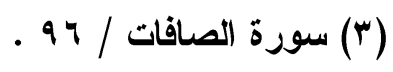


وقد اختلف الأثثاعرة والماتريدية في بيان وجه دلالة هذه الآيـة، علىى

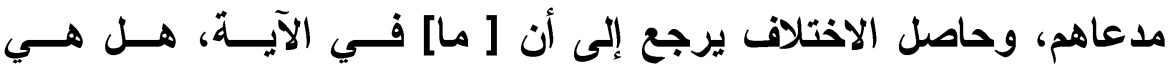

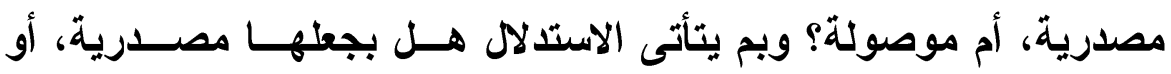

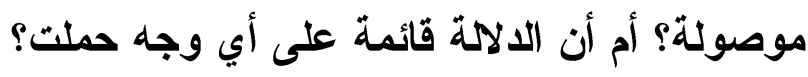
أولاً : اعتبار أن [ما] مصدرية :

وإلى هذا الحمل ذهب الجمهور حيث استدلوا بهذه الآية على أن فعل العبد مخلوق لله تعالى، محتجين في ذلك، بأن النحويين اتفقوا على أن [ما] مع

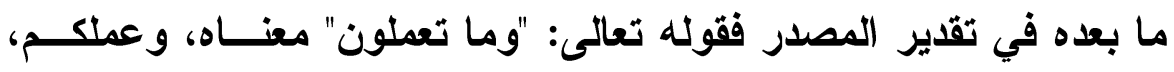
وعلى هذا التقاير صار معنى الآية والله خلقكم وخلق عملكم(1)

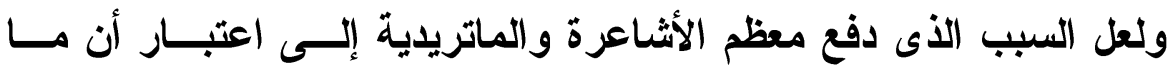

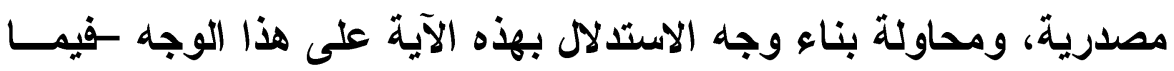
نرى - هو أن المعتزلة بالغوا في جعل [ما] موصولة، وأوردوا اعتراضات

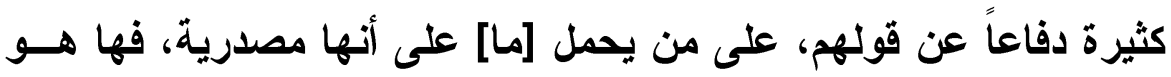
الزمخثري يقول معنى الآية والله خلقكم وخلق ما تعملونه من الأصــنام،

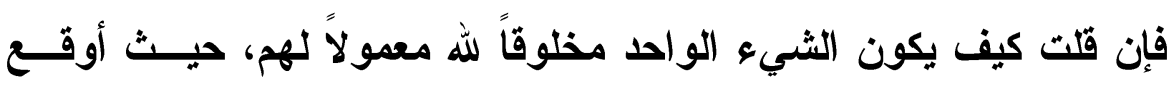

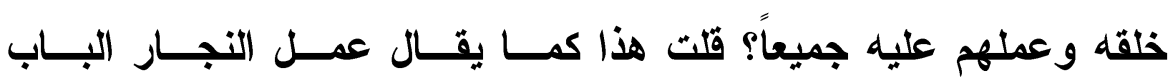

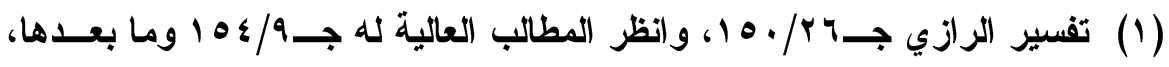
ولقد استدل الإمـام أبو البركات النسفي بالآية أيضاً حاملاً لها على هذا الوجـهـ، انظــر

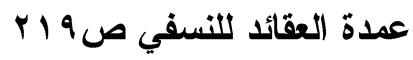


و الكرسي... والمراد عمل أشكال هذه الأشياء، وصورها، دون جواهرها، والأصنام جواهر وأثكال، فخالق جواهرها الله، وعاملوا أثــكالها الـــين

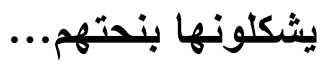

فإن قلت فما أنكرت أن تكون [ما] مصدرية لا موصولة، ويكون المعنـى والله خلقكم وعملكم كما تقوله المجبرة؟ - يقصد بالمجبرة كل من خــالف المعتزلة في قولهم في فعل الإنسان بما في ذلك الأثـاعرة و الماتريدية قلت أقرب ما يبطل به هذا السؤال بعد بطلانه بحجج العقــل والكتــاب أن معنى الآية يأباه إباء جلياً، وينبوا عنه نبواً ظاهراً، وذلك أن الله عز وجل قد احتج عليهم بأن العابد والمعبود جميعاً خلق الله تعـالحى فكيـف يعبـــ المخلوق المخلوق، على أن العابد منهما هو الأى عمل صــورة المعبـود وشكثله، ولولاه لما قدر أن يصور نفسه ويشكلها، ولو قــت والله خلقكـم وخلق عملكم لم تكن محتجاً عليهم، ولا كان لكلامك طباق... ويضيف الزمخثري، أن ما تعملون ترجمة عن قوله تعالى قبل ذلك ج قَال

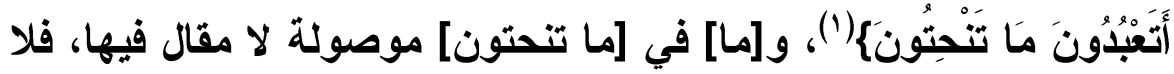
يعدل بها عن أختها إلا متعف متعصب لمذهبه ().

(1) سورة الصافات / م / 90

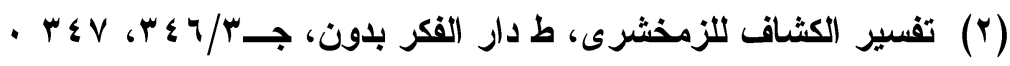


و إذا كان الزمخشري قد بالغ في حمل [ما] على أنها موصولة، فلقد بـالغ الإمام ابن المنير، على حمل [ما] على أنهــا مصــرية، قاصــراً وجــه الاحتجاج على هذا الحمل، قائلاً يتعين حملها سما- علــى المصــدرية(1) متتبعاً كلام الزمخشري، وما أورده من اعتراضات على حمل [مــا] علـى

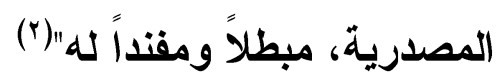
ولقد وصل الأمر ببعض أئمة الأثشاعرة والماتريدية أن يرى أن الأولـى ترك الاستدلال بهذه الآية، وذلكك لما رأى من كثرة اعتراضــات الخصــوم على أن [ما] مصدرية، فها هو الإمــام الـــرازي، بعـــ أن يــورد كــلام الزمخثري السابق واعتر اضاته على من حمل [ما] على أنها مصدرية -

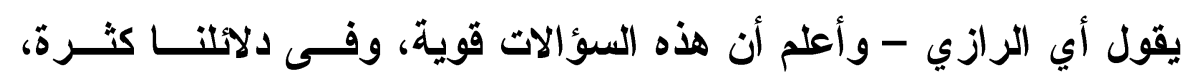
فالأولى ترك الاستدلال بهذه الآية"(r). ثاتياً : الاستدلال بالآية قائم على أي وجه حمث [ما] : لم تقف جهود الأثاعرة والماتريلية، في بيان وجه الاستدلال بهذه الآية، على جعل ما مصدرية، ذلك أن المحققين منهم يرون أن الاستدلال بالآيــة قائم حتى على اعتبار جعل ما موصولة، ومن هؤلاء الإمام أبــو المعـين

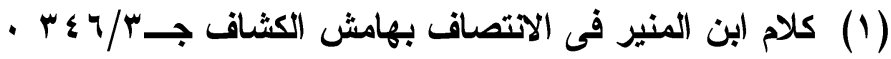

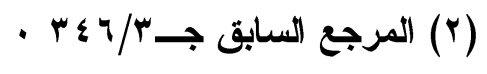

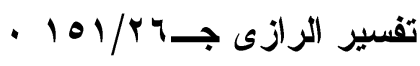


النسفي، والإمام السعد التفتاز اني، ومن تابعهما على قولهمــا مـن أهـلـ التحقيق، كالإمام الظواهري، والثيخ أبى دقيقة. يقول أبو المعين النسفي "على أنا وإن صرفنا الآية إلى المعمول، وجعلناه كأنه قال، والله خلقكم ومعمولكم، فالاستدلال بالآية باق، لأن الله تعـالى لا يكون خالقاً للمعمول، لو لم يكن عملهم مخلوقاً له، لأن ذلك الجسم بـدون عمل العباد لا يكون معمولاً، وهو تعالمى أثبت الخلق للمعــول، فــدل أن العمل الأى صار به الجسم المخلوق معمولاً كان مخلوقاً له حتــى جعـل

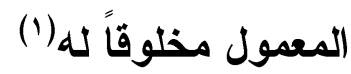

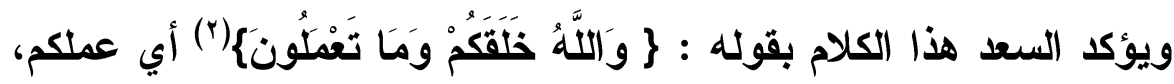
على أن ما مصدرية، لئلا يحتاج إلى حذف الضمير، أو معمولكم، على أن ما موصولة، ويشمل الأفعال، لأنا إذا قلنا أفعال الإنسان مخلوقة لله تعالى أو للعبد؟ لم نرد بالفعل المعنى المصدري الأى هو الإيجاد، والإيقاع، بـلـل الحاصل بالمصدر الأى هو متعلق الإيجاد والإيقاع، أعنى ما نشاهده، من

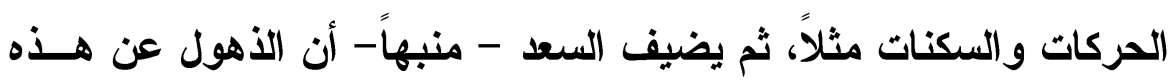
النكتة قد يوهم أن الاستدلال بالآية موقوف على كون ما مصدرية().

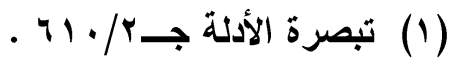

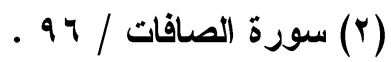

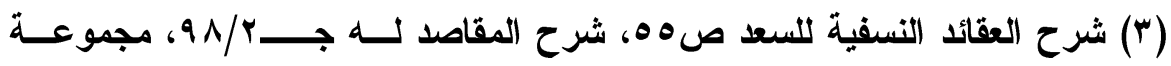

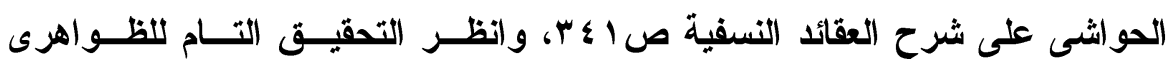




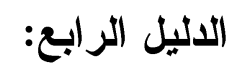

الاستـلال بالأحاديث التي وردت في القضاء والقــــ، وهـــه الأحاديــث متو اترة في المعنى، وإن كانت ألفاظها آحاداً، يقول الإمام السعد "الأحاديث الواردة في باب القضاء، والقدر وكون الكائنات بتقدير الله، ومشيئته وإن

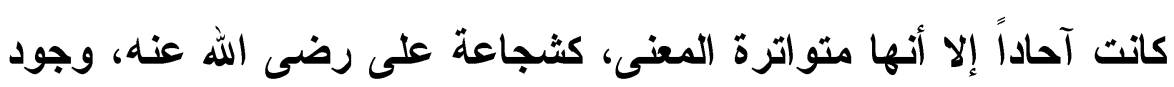
حاتم وكلها صحاح، بنقل الثقاة مثل البخاري، ومسلم وغيرهما"( (1). ومن هذه الأحاديث ما روى عن على رضى الله عنه، قال رسول الله صلى الله عليه وسلم: لا يؤمن عبد حتى يؤمن بأربع، يشهـ أن لا إلـهـه إلا الله،

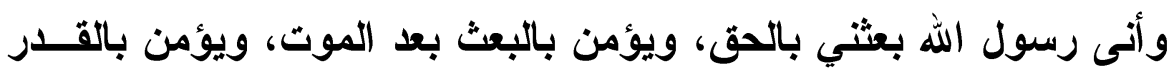

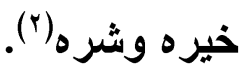
ومن ذلك أيضاً ما روى عن حذيفة رضى الله عنه أنه قال: قال رسول الله صلى الله عليه وسلم إن الله تعالى يصنع كل صانع وصنعته (").

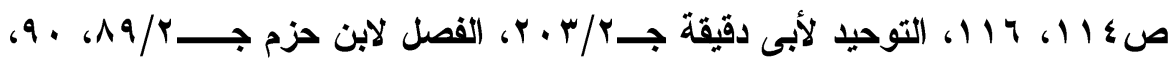

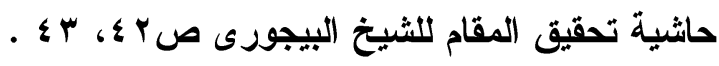

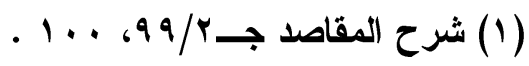

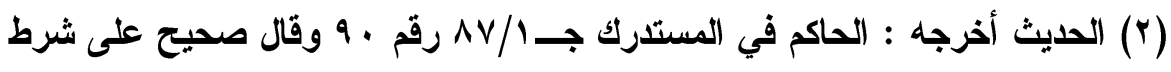

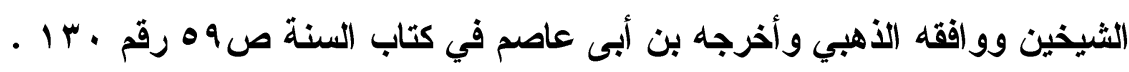

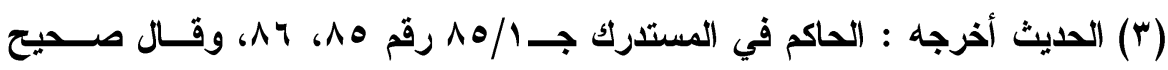
على شرح مسلم ولم يخرجه وو افقه الذهبي، وأخرجه بن أبى عاصم في كتاب الســنة

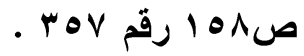


يقول الباقلاتي في الاستدلال بهذا الحديث، وصــنعة الصــانع إنمـا هـي بحركاته، وأفعاله سواء كان ذلك في صنعة مباحة أو محظورة ... فصــح بهذا الخبر أن الله تعالى خالق للفاعل منا ولفعله(1)والأحاديث الصــيحة في هذا (الباب كثيرة(†).

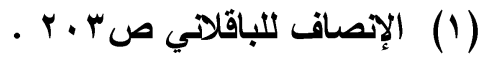

(r) الاعتقاد للبيهقي صمى ا وما بعدها، فقد أورد الإمام البيهقي أحاديث كثيرة تدل على قول أهل السنة من أن الله تعالى هو الخالثى لأفعال العباد. 
المبحث الرابع

القدرة الحادثة و أثرها في الفعل الإساني عند الأشاعرة و الماتريدية : القدرة والاستطاعة، والقوة، والطاقة عند الأشـاعرة والماتريديــة بمعنــى واحد، بل في مصطلح أهل الكلام -عموماً- على حد تعبير أبـى المعـين النسفي يريدون بها كلها شيئًاً واحداً، إذا أضافوها إلى العباد، ويجلونهـــا في عرفهم بمنزلة الأسماء المتر ادفة"(1). ومعناها كما يوضحه الإمام السعد " هي الصفة التي بها يتمكن الحيــوان من مزاولة أفعال شاقة، ويقابلها الضعف"(؟).

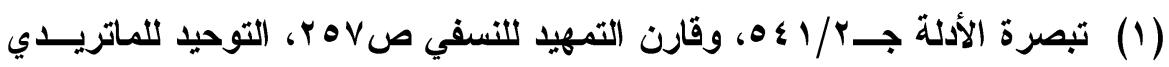

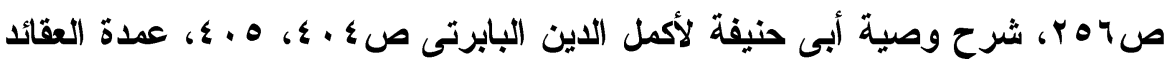

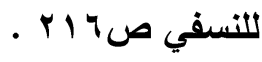

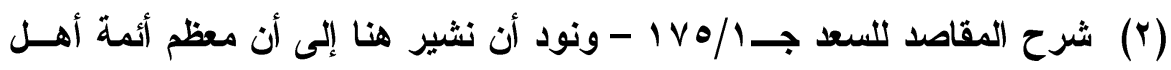
السنة عندما يتكلمون عن الاستطاعة في مبحث أفعال العبـاد، فإنمــا بعنــون بهـا، الاستطاعة التي هي عرض مقارن للفعل، والتي سوف يكون حايثنا فى هـــه الفقـرة عنها وإن كان بعض أهل السنة وخاصة الماتريدية عندما يتكلمون عـن الاســنطاعة فإنهم يقسمونها إلى قسمين : الأول : الاستطاعة بمعنى سلامة الأسباب، وصحة الآلات، وهذه الاســتطاعة متقدمــة على الأفعال باتفاق، ولكن حقيقتها ليست بمجعولة عللاً للأفعال، وإن كاتت الأفعـال لا تقوم إلا بها، حيث أجرى الله تعالى عادته أن من كان سليم الأعضاء، صــيح الآلات، عندما يقصد الفعل يخلق الله تعالى له القدرة التي هي عرض مقارنة لهزا الفعل، 
هذا ونستطيع أن نتناول كلام الأشاعرة والماتريدية في الاسـنطاعة، أو القدرة الحادثة من خلال نقاط ثلاث :

الأولى : إثبات القدرة الحادثة وطرق العلم بهـــــا.

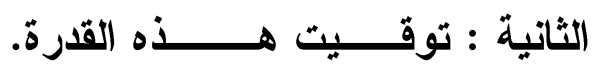
الثالثة : هل القدرة الحادثة تصلح للضدين أم لا؟ وهاتك كلام الأثشاعرة والماتريدية على هذا النحو من الترتيب. أولاً : إثبات القدرة الحادثة وطريق العلم بها : على خلاف مما ذهب إليه الجبرية الخالصة، من نفى قدرة الإسسان أصلاً،

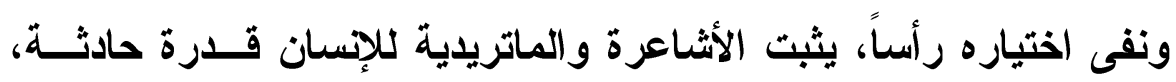

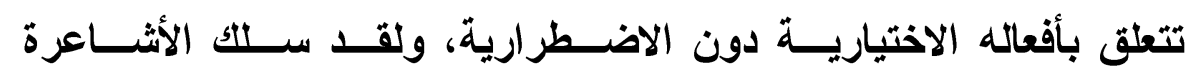

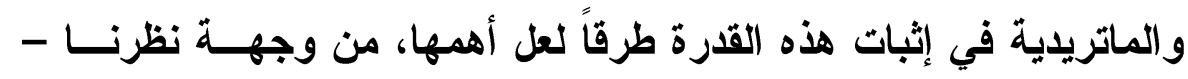
طريق الوجدان، وهو الأى ركز عليه الأثاعرة، وكثير من الماتريدية. وحاصل القول في هذه الطريق، أن العاقل يجد من نفسه تفرقة ضــرورية بين قيامه وقعوده وكلامه، إذا كان و اقعاً بحسب اختياره، وقصده، وبين ما

الثاني : الاستطاعة - التي هي عرض - وهى على حد تعبير أبى المسين، "مغنسى لا

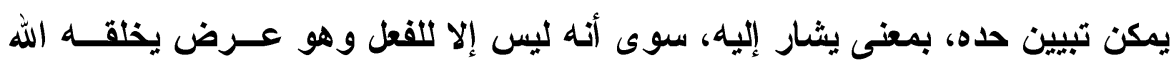

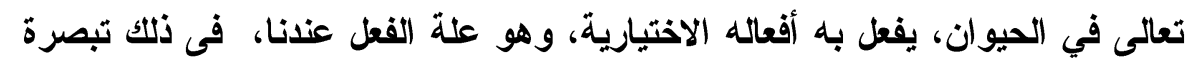

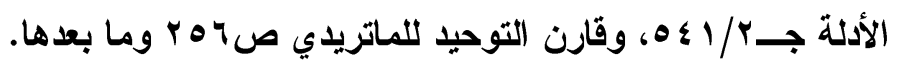


يضطر إليه من أعمال، مما لا قلرة له عليـهـ مسن الزماتسـة، والمـرض و الحركة من الفالج وغير ذلك. يقول الآمدي، وأما أهل الحق من الأثشاعرة فقد استدلوا على ثبوت القدرة الحادثة بما يجده العاقل من نفسه من التفرقة الضــرورية بــين حركتــهـ

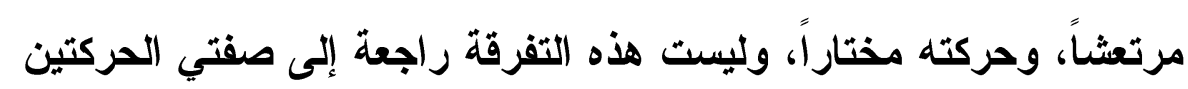
إذ لا اختلاف بين الحركة الاضطرارية والاختيارية، من حيث هي حركة إلا هردئ

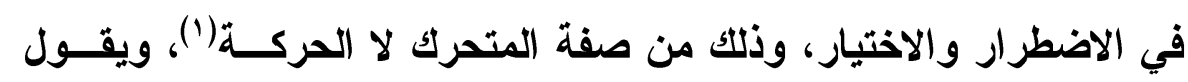
الإمام الإيجي القدرة الحادثة تعرف ويعلم وجودها بالوجدان (). ولتوضيح هذا الكلام، يقول الأثثاعرة والماتريليــة ، نفتــرض حسركتين،

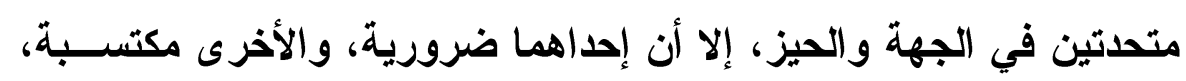

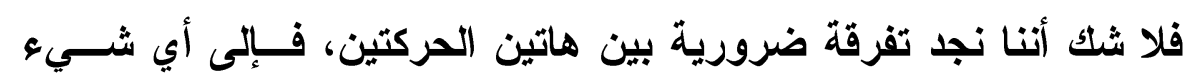

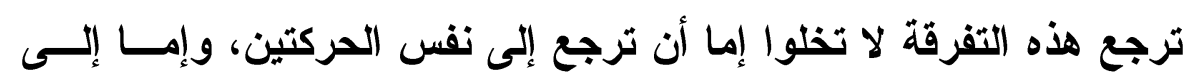
ذات المتحرك وإما إلى حال طرأت على الفاعل، وإما أن تكون راجعة إلى إلى صفة زائدة على ذات المتحرك أما رجوع التفرقة إلى نفس الحركتين فباطل، وذلك لتماثلهما، أما رجـوع

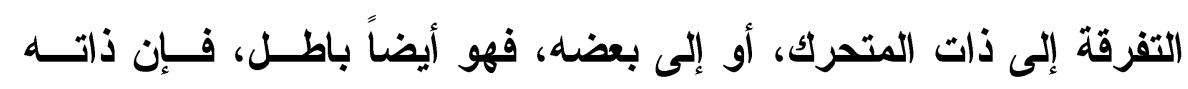

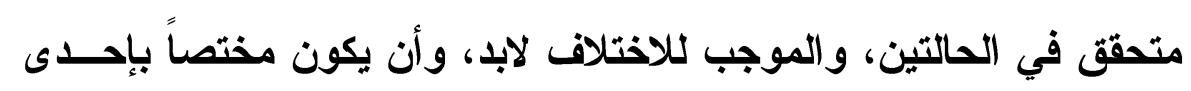

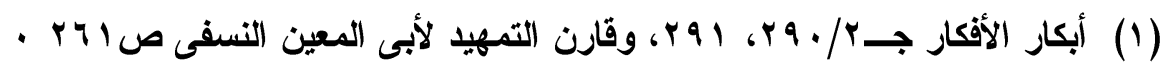

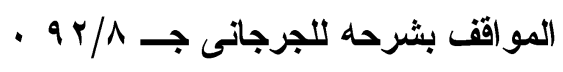


الحالتين دون الأخرى، وإذا بطل رجوع التفرقة إلى نفس الحــركتين، أو إلى ذات المتحرك، تعين رجوعها إلى شيء زائد، ولا يخل هذا الزائد إمــا أن يكون عدماً، أو وجوداً، أو حالاً لا يتصف بالوجود ولا بالعدم، أما كونه عدماً فهو محال، وذلك لأن العدم نفى محض، والنفي المحض لا يصح أن يكون له تعلق إيجابي، ومحال كذلك أن ترجع التفرقة إلى طروء حال على المتحرك، وذلك لأن الحال لا تطرأ على الجواهر، وإنما تكون تابعة لوجود

موجود

وإذا بطل أن ترجع التفرقة إلى هذين الاحتمالين، لم يبـق إلا أن ترجـع التفرقة، بين الحركتين إلى وجود، ثم هذا الوجــود لا يجــوز أن يكـون جوهراً، لأن الجوهر لا أثر له في الجوهر، فتعين أن يكون الزائد عرضاً، وتعين كذلك أن يكون هذا العرض قدرة، إذ كل صفة من صفات المكتسب

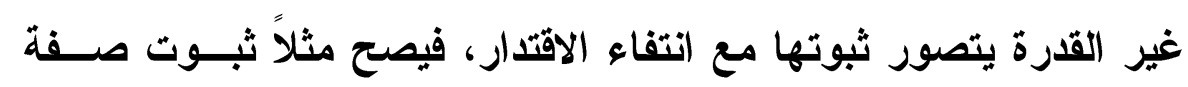

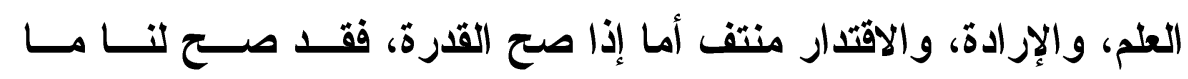

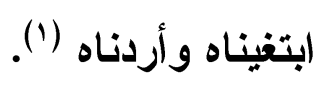

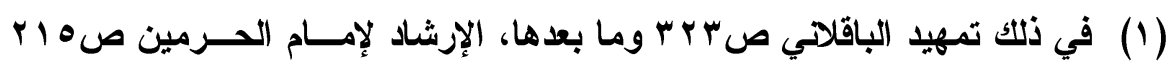

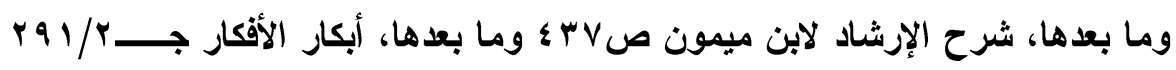

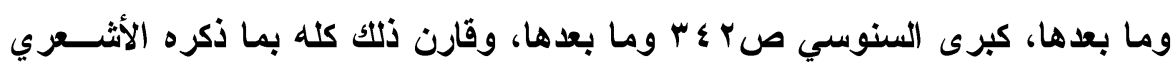

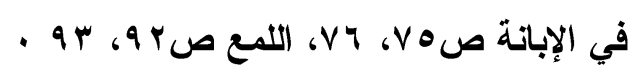


ثانياً : مقارنة القدرة الحادثة للمقدور بها :

يقرر الأثشاعرة والماتريدية أن هذه القدرة الحادثة تقارن المقـدور بهـا، بمعنى أن توقيت حدوث هذه القدرة للعبد يكون مع المقدور بها، فلا تثقدم عليه، ولا تتأخر عنه، وهذا ما يعبر عنه غالباً، بأن الاستطاعة مي الفعل، يقول الإمام أبو حنيفة رحمه الله " نقر بأن الاستطاعة ميع الفعل، لا قبـل

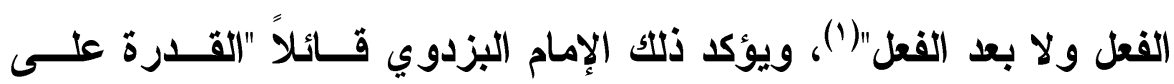
الفعل، لا تسبق الفعل، بل تكون مع الفعل، وإن القدرة لا بقاء لها، وأبــو حنيفة رئيس في هذه المسألة"("). و القول بأن الاستطاعة مع الفعل، لا متقدمة عليه ولا متأخرة عنـه،ه، هـو محل إجماع من الأثشاعرة والماتريدية، يسجل أبو المعين النسـفي هــــا الإجماع بقوله " قال أصحابنا - الماتريدية وجميع متكلمي أهل الحسديثيقصد الأثشاعرة- والنجارية إنها -الاستطاعة- تكون مع الفعل، ومحسال تقدمها على الفعل"("). - (ت).

(1) انظر وصية الإمام أبى حنيفة بشرحها لأكمل الاين البابرتي ص ؛ ــ . .

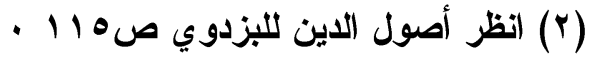

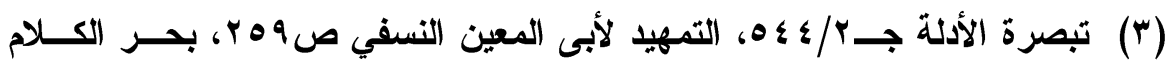

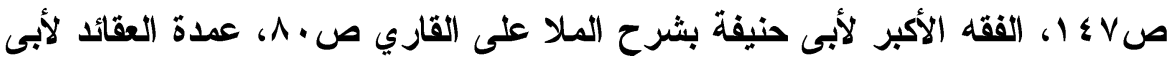

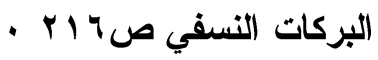


ويقول الآمدي "مذهب أهل الحق من الأشاعرة، أن القدرة الحادثة لا تتقدم

على مقدورها، ولا تتعلق بـه قبل حدوثه، بل وقت حدوثهه"(1) منطلق الأثاعرة والماتريدية في قولهم بأن القدرة الحادثة مقارنة للمقدور

بها?

لقد انطلق الأشاعرة و الماتريلية في ذلك من تقرير هم أن القدرة الحادثــة عرض، ومن منطلق قولهم إن العرض لا يبقى زمانين. يقول الإمام السنوسي "فالحكم بأن القدرة مقارنة للمقدور بها، ثابت لهـا من حيث كونها عرضاً"(r).

إذن، فلما كاتت القدرة عرضا من الأعراض، وكاتت الأعـــراض يسـتحيل بقاؤها، وكان المقدور لابد أن تتعلق به القدرة، لزم على هذه الأصول أن تقارن القدرة المقدور، ولا تثقدم عليه، لأن القدرة لو تقدمت عليه لعدمت في حال وجود المقدور، وقد علمنـا العلاقة بين القــدرة والمقــدور حتـى

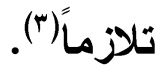
وتأكيد الأشـاعرة والماتريدية على مقارنة القدرة الحادثة لمقـدورها مــن حيث عرضيتها، إثـارة منهم إلى وجوب التفرقة بين القدرة الحادثة وبين القدرة القديمة، التي هي صفة لله عز وجل، فلا ينبغــي أن يعـــم حكـم

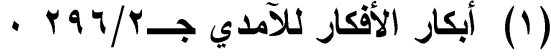

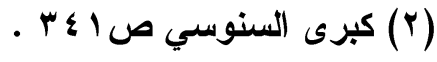

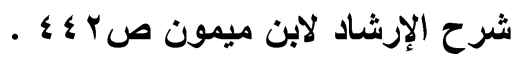


المقارنة على كل قرة، فيشمل القدرة الإلهية، إذ هي ليســث مسن قبيـل

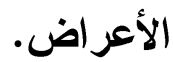

ينص على ذلك إمام الحرمين قائلاً، لو قرنا سبق الاعتقاد إلى بقاء القدرة الحادثة، لما استحال تقدمها على وقوع مقدورها، ولذلك يجب القطع بتقدم القدرة الأزلية على وقوع المقدورات بها، فلما ثبت أن القدرة الحادثــة لا تبقى ترتب على ذلك استحالة تقدمها على المقدور، فإنها لو تقدمت عليه، لوقع المقدور مع انتفاء القدرة وذلتك مستحيل('). ولقد استدل الأثـاعرة والماتريدية على مقارنة القدرة الحادثــة للمقــدور،

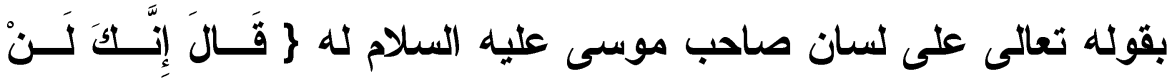

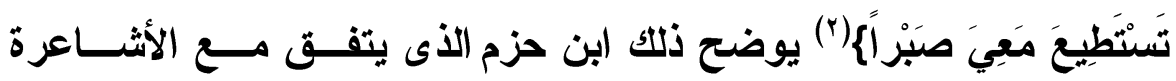
والماتريدية في هذه المسألة، قائلاً، لم يقل موســى عليـــه الســلام إنــي

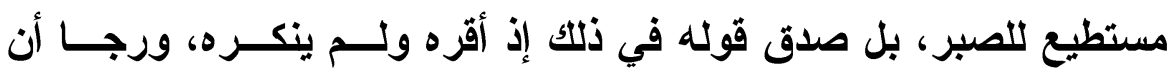
يحدث الله تعالى له استطاعة على الصبر فيصبر"(").

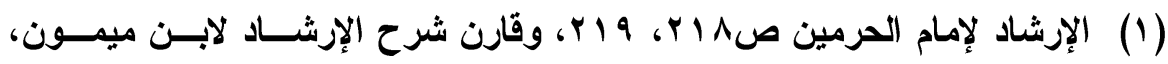

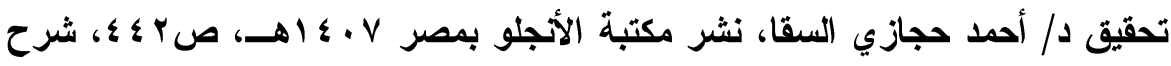
الإرشاد للمقترح، تحقيق د/ فتحي أحمد عبد الرازق، رسالة دكتور اه، مخطوطة بكليــة

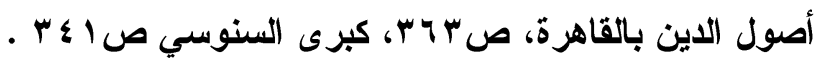

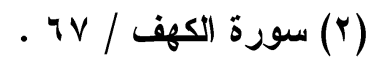

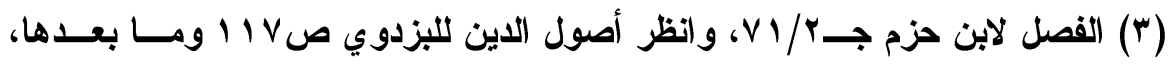

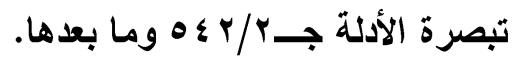


ولكن قل يعترض على كلام الأثشاعرة والماتريدية - بأنه علـى التسـليم

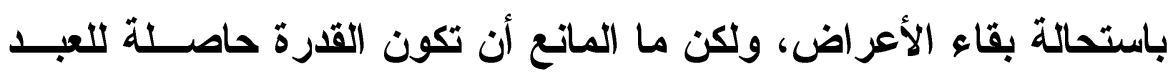

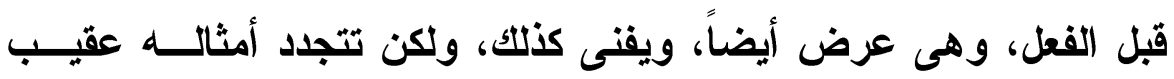
زواله، فما الذى يمنع من ذلك؟ب(') و هنا يجيب الأثثاعرة و الماتريدية إجابة دقيقة، حاصلها، أنسـه ينبنسي أن

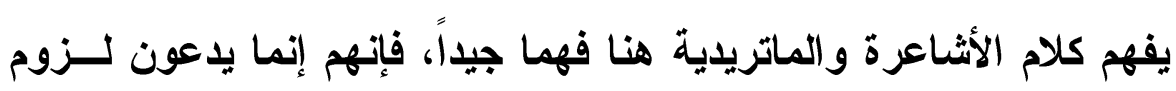
وقوع الفعل بدون قدرة إذا كانت القدرة التي سيقع بها الفعل، هي القــدرة السابقة، وهى عرض ولا ييقى، فإن وجدت هذه القدرة بعينها قبل الفعل، مع ملاحظة عرضيتها، وعدم بقائها، فعند ذلك وقوع الفعل بلا قـــرة لازم

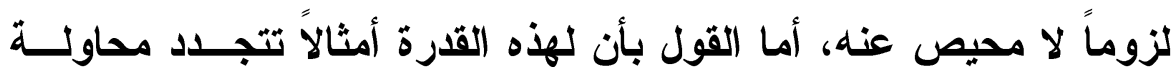

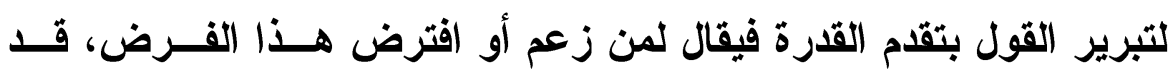
اعترفت بأن القدرة التي يكون بها الفعل لا تكون إلا مقارنة له، ولا يخـل

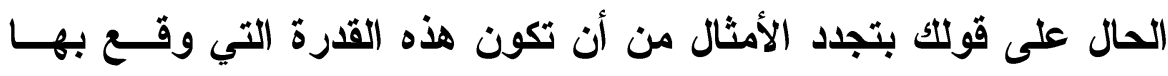

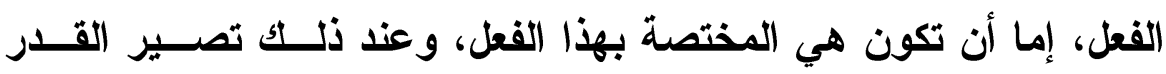
السابقة التي هي أمثال لهذه القدرة المقارنــة ضــائعة، لا يرجسى مسن وجودها، وسبقها، فائدة، بل وجودها كعدمها حيث لم يحصل بها الفعل.

(1) الكفاية للصابوني ص 9 ـ 1، وقارن شرح العقائد النسفية ص ـ "، 1" . 
وإن كانت هذه القدرة المقارنة، إنما هي لفعـل آخـر يعقبهـا، وليســـ بمختصة بما قارنها من فعل، فيلزم وقوع الفعل بلا قدرة كما قلتـا، ولــو جاز حصول الفعل بلا قدرة، لجاز حصوله مع العجز -وهو ظاهر الفساد (1). ربما اعترض المعتزلة من أن القدرة لو كانت مقارنة للمقدور، لما كسـان أحدهما بأن يكون قدرة على صاحبه بأولى من العكس. وهذا الاعتراض في نظر الأثشاعرة والماتريدية واهِ، فها هي حركة اليا مع حركة المفتاح ودخول الحجر في القدح مع خروج الماء منه، فهذه أفعـال متقارنة، والسبب معروف فيها من المسبب (ץ). ويؤكد الإمام الصابوني هذا المغنى بقوله "تو افقتا على أن الفعل مستحيل، بقدرة سابقة على الفعل بأزمان كثيرة متى كاتت معدومة وقت الفعل، فكذا يستحيل -الفعل- بقدرة سابقة عليه بزمان واحد، لأن العدم في الحسال لا لا

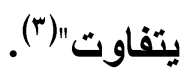

هل تصلح القدرة الحادثة للضدين؟ هل يقدر الإسـان بهذه القدرة التي ثبتت له، على فعل الخيـر والثــر، أو على فعل الطاعة والمعصية؟ ويمعنى آخر هل يأتي الإسان أفعالــه التــي

(1) تبصرة الأدلة لأبى المعين النسفي جـ ؟/. ؟ه بتصرف يسير، وقارن الفصل لابن

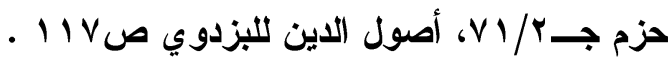

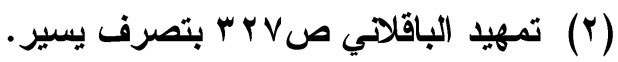

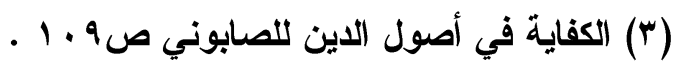


تتنوع إلى طاعة ومعصية بقدرة واحدة؟ أم أنه يحتاج بإزاء كل مقدور إلى

قدرة تخصه وتناسبه، بحيث لا تصلح هذه القدرة إلا لهذا المقدور؟! اختلفت أقوال الأشاعرة والماتريدية في الإجابة على هذا التساؤل، حيــث تبنى الأشاعرة وبعض الماتريدية قولا، وتبنى بعض الماتريدية قولا آخـر وإليكم تفصيل هذا الكلام: أولاً : قول الأشـاعــرة :

ذهب الأشـاعرة إلى أن القدرة الحادثة لا تصلح للضدين، فقـدرة الإيمسـان غير قرة الكفر، وقدرة الطاعة غير قدرة المعصية، وقد بنـى الأشـــاعرة قولهم هذا على القول بأن القدرة الحادثة مقارنة للمقدور بهــا، إذ معنـى المقارنة أن وجود القدرة مرتبط ومقترن بوجود الفعل، ومن ثــــ فهنــاك مناسبة بين القدرة والمقدور بها، وهذا ما يعنيه الأثناعرة بأن قوة الإيمان توفيق، وقوة الكفر خذلان، فأنى تصلح إحداهما للآخر؟ هذا من جهة

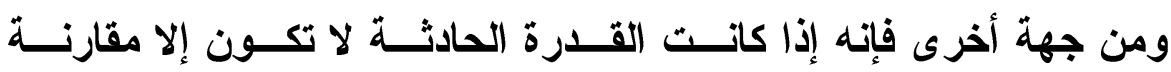
لمقدورها، فلو صلحت هذه القدرة للضدين، لأدى ذلك إلى جــواز اقتــــان الضدين ووجودهما معاً، وهو محال ظاهر الإحالة. (1).

(1) في ذلك اللمع للأشعري صع 9، ه9، أصول البزدوي صس ب ا، تبصرة الأدلــة

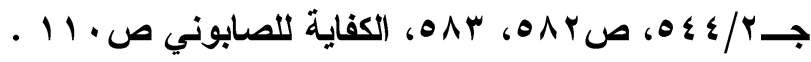


ويقول السعد في ذلك "يتفرع على كون القدرة مــع الفعـل - أن القــدرة الواحدة لا تتعلق بمقدورين سواء كانا ضدين، أو مثلين أو مختلفين - فإن ما نجده في نفوسنا عند صدور أحد المقدورين، غير ما نجده عند صدور

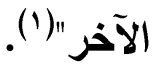

وينص إمام الحرمين على ذلك بقوله القدرة الحادثة لا تتعلق إلا بمقــور

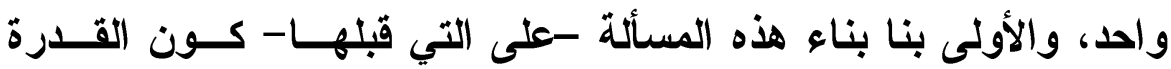

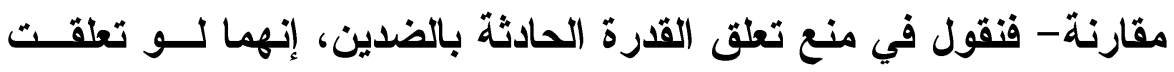

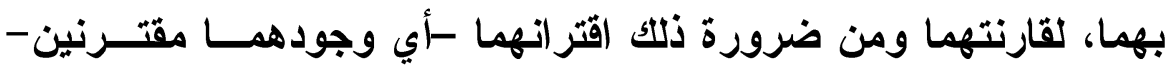
وهو باطل على الضرورة، فــإن اســتحالة اجتمــاع الضـــين مدركــة

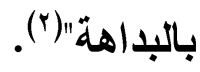
هذا ولقد تبنى بعض الماتريدية أيضاً، نفس القول من أن القدرة الحادثة لا تصلح للضدين، لعل من أهم هؤلاء الإمام أبو منصور الماتريـــى فــأكثر كلامه كما يقول أبو المعين النسفي يدل على أنه يميل إلـى أن القـــرة لا تصلح للضدين"(")

$$
\text { (1 ) شرح المقاصد جـ/1) }
$$

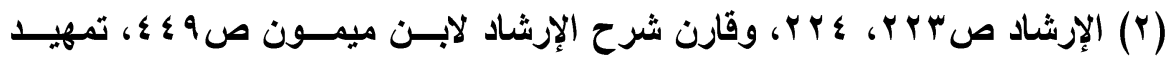

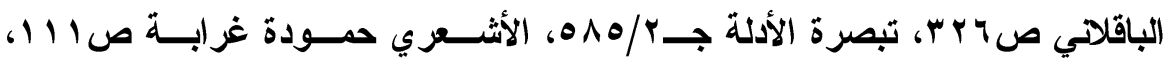

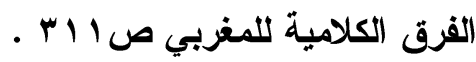

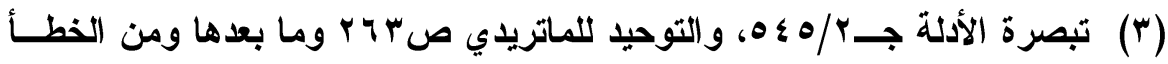
بمكان أن يحاول بعض الباحثين جعل القول بصلاحية القدرة للضدين قولا للماتريـــي، 


\section{$\wedge \wedge 1$}

ولو تأملنا في القول بأن القدرة الحادثة لا تصلح للضدين، وقارنا ذلك بما سبق من اتفاق الأشـاعرة والماتريدية على أن القدرة الحادثــة، مقارنـــة للمقدور بها، لوجدنا أن هنالك تناسقاً فكرياً، فالقدرة لمـــا كانــت مقارنـــة للمقدور بها، فكأنها متعينة ومتخصصة لهذا المقدور الأى وقع بها، ولما يكون الأمر كذلك، فلا تصلح هذه القدرة لأن يفعل بها فعلين ســواء كانـــا ضدين أو مثلين، وإلا للزم وجود الضدين في آن واحد لملاحظة المقارنــة التي قال بها الأشاعرة والماتريدية.

ومن ثم فلا عجب أن ينتج من هذا كله، القول بأن القادر على الطاعة غير قادر على المعصية، في نفس الوقت بقدرة الطاعة (1). هذا ولم يسلم كلام هذا الفريق من الأشـاعرة والماتريدية، من أن القــدرة الحادثة، لا تصلح للضدين، من إيراد الاعتراضات عليه، لعل أهمها أن ذلك يؤدى إلى أن يكون الكافر في حال كفره غير قادر على الإيمان، الأى هو مكلف به، ويؤدى ذلتك إلى أن يكون التكليف بالإيمان وارداً مع عدم القدرة

أو القول بأن الماتريدى قال بهذا القول محاولة منه للوصول إلى رأى المعتزلة، ولعـل

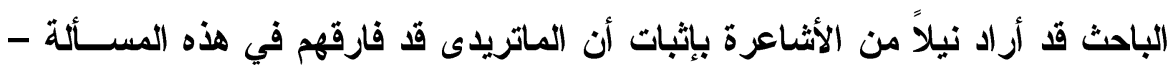
و هذا خطأ، مقدمة مناهج الأدلة، د/ محمود قاسم صه 11 11، 119

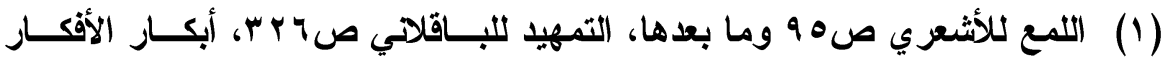
للآمدي جـ/ 
عليه، فيكون تكليفاً بما لا يطاق، فيتأدى هذا القول بالمذهب إلى الوقـوع

في الجبر الذى حاول الفرار منه!!! (').

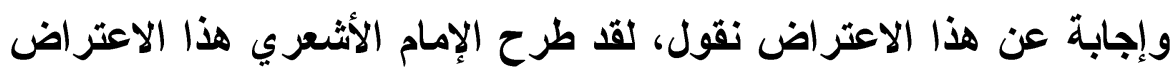
وأجاب عذه بما حاصله، أن ما لا يطاق، الذى ورد في الاعتــراض يقــال

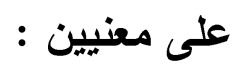

أحدهما : مالا نطيقه، لأنا اخترنا ضده، وصرفنا جهـنا إليه.

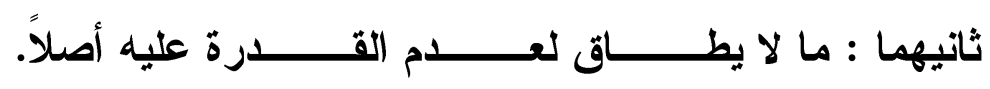

ولو تأملنا لوجدنا أن اللازم للقول بعدم صلاحية القدرة للضدين، هو مسالا

يطاق بالمعنى الأول، حيث جاء عدم الإطاقة من الإسـان الكـافر للإيــان

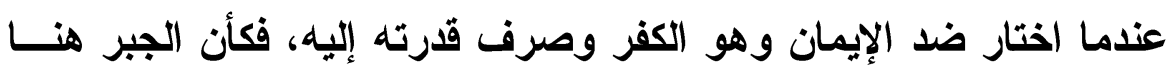

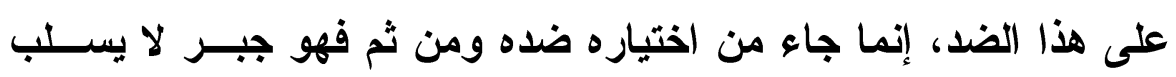

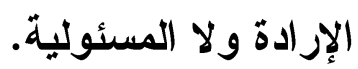

وأما المعنى الثاني لما لا يطاق، فهو غير لازم لكلام الأثاعرة والماتريدية

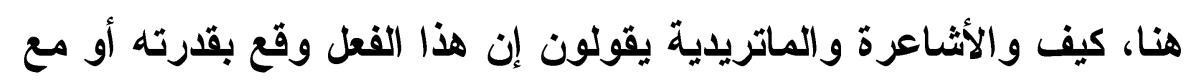

قدرته؟(")

(1) أبكار الأفكار جـr/ • r/، وقارن التمهيد للباقلاتي ص آب وما بعدها.

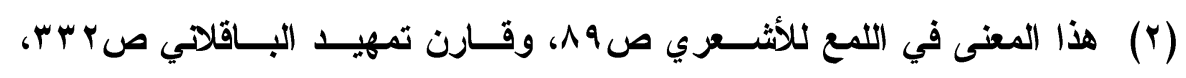

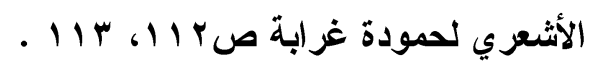


ولقد أكد الإسفرايينى هذا التخريج الأى خرجه الأشعري فيما يحكيه عنـهـ

الإمام أبو المعين النسفي(')

ويجيب الآمدي كذلك "إن عنيتم بكونهـه مضطراً، أن فعلـهـه غيـر مقــدور، فممنوع، وإن عنيتم بكونه مضطراً، أن مقدوره، ومتعلق قدرته متعـين، وأنه لا مقدور له بهذه القدرة سواه، فهذا هو عين ما رمناه،. (ץ) ويدفع أبو المعين النسفي هذا الاعتر اض مبيناً أنه إذا لم يكن مع الكــافر حالة كفره قدرة الإيمان، إلا أن انعدام قدرة الإيمان كــان بتضــيبعه هــو لاشتخاله بضده -أي الكفر -، لا بمنـع القدرة عنه، ومن منـع عنه القـــرة، فهو معذور، أما من ضيع القدرة فهو غير معذور بل معاتب ومعاقب، فإن الله تعالى، قد أجرى عادته أن من كانت له أعضاء صـــيحة، وأســباب سليمة لو قصد فعلاً أعطاه الله تعالى قرة ذلك الفعل وفى المثــال الـــى معنا، لم يعطه قرة الإيمان لإعر اضه عنه، وأعطاه قدرة الكفر لاثــتغاله به، فكان مضيعاً لقدرة الإيمان (ז). ثانياً : قول بعض الماتريدية في صلاحية القدرة للضدين : ذهب بعض الماتريدية إلى أن القدرة الحادثة تصلح للضدين متمسكين في ذلتك، بما روى عن الإمام أبى حنيفة من أن القدرة الحادثة تصلح للضدين،

$$
\begin{aligned}
& \text { (1) تبصرة الأدلة جـ/ ONV، }
\end{aligned}
$$

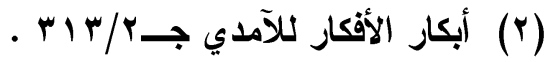

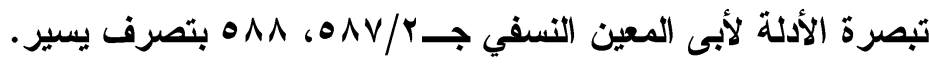


يقول الإمام أبو منصور الماتريدى "قال جماعة هــي -القــــرة- تصــلح للأمرين جميعاً، وهو قول أبى حنيفة وجماعته"(').

وريما أثكل قول أبى حنيفة بأن القدرة الحادثة تصلح للضدين؟، فهل هولئه

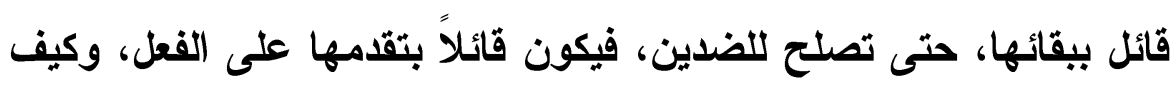
نوفق بين قوله هنا بالصلاحية، مع اعتر افه وإقراره الذى لم يبرح آذانتـا

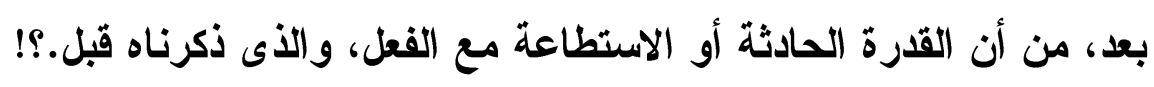

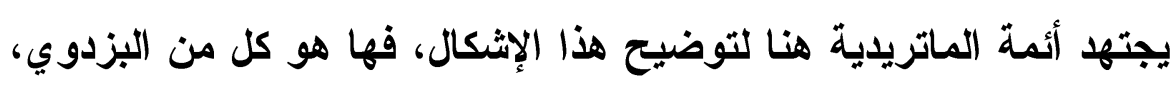

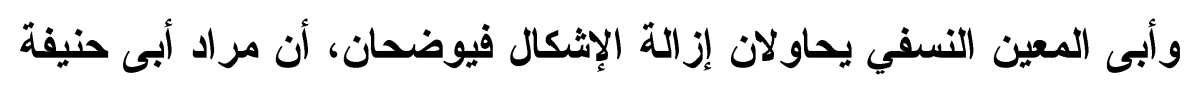

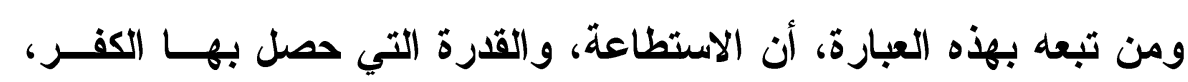
صالحة له، ولا تصلح للإيمان حال اقترانها بالكفر، ولكن لو اقترنت نفس لون

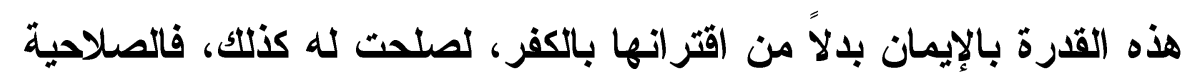

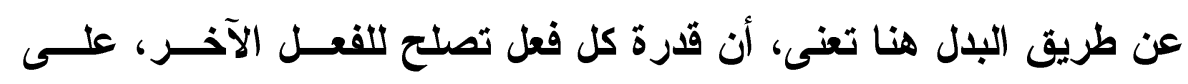

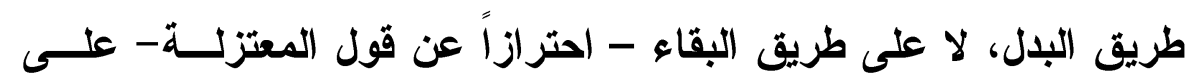

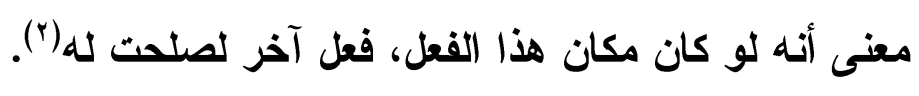

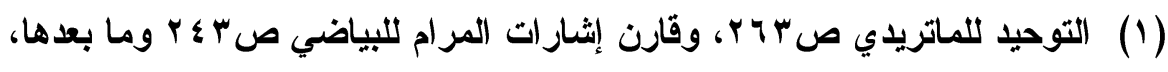

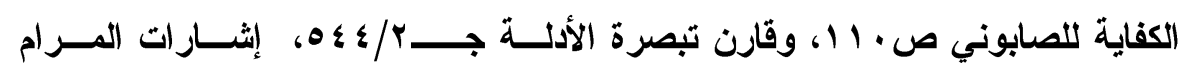

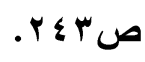

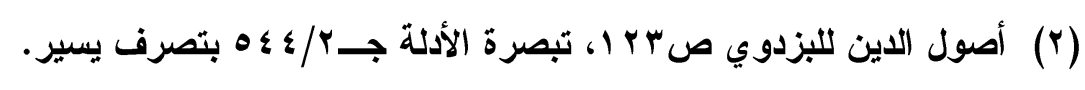


ويزيد ملا على القاري الأمر توضيحاً بقوله، إن القدرة صالحة للضــدين عند أبى حنيفة، حتى إن القدرة المصروفة إلى الكفر، هي بعينها القـــرة التي تصرف إلى الإيمان، لا اختلاف إلا فــي التعلـق، وهـــ لا يوجــب الاختلاف في نفس القدرة، فالكافر قادر على الإيمان المكلف به، إلا أنـــه صرف قدرته إلى الكفر، وضيع باختياره صرفها إلى الإيمان، فاستحق الأم والعقاب، من هذا الباب('). وجه قول أبى حنيفة ومن تبعه: احتج هذا الفريق في تأييد قوله بعدة وجوه منها : الوجه الأول: أنهم قاسوا القدرة، من حيث إنها سبب من أسـباب الفعـل، على بقية الأسباب والآلات، ولما كاتت الآلات المعدة، للفعل تصلح للضدين فاللسان مثثلاً يصلح للصدق والكذب، قــالوا إن القـــرة الحادثــة تصــلح للضدين، كبقية الأسباب والآلات (؟). الوجه الثاني: أراد هذا الفريق أن يتحاثى ما قد يرد على القــول بعـدم صلاحية القدرة للضدين، من اعتر اضات، كلزوم تكليف ما لا يطاق مـثنلاً ولذا نرى أبا المعين النسفي يقول "القدرة لو كانت لا تصلح للضدين، لكان

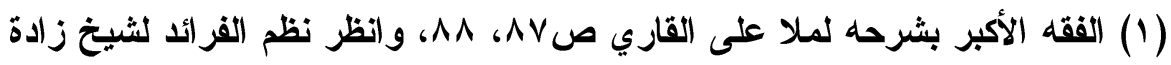
صז" § ؛ وما بعدها.

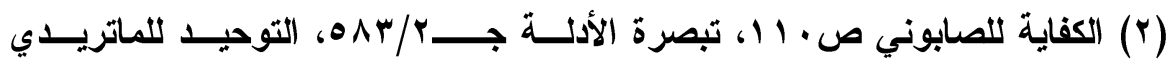




\section{$\wedge \wedge \uparrow$}

فيه تكليف مالا يطاق، على ما بينا أن الكافر مأمور بالإيمان، فلو لم تكـنـ

معه القدرة الصالحة للإيمان، لكان فيه تكليف مالا يطاق"('). الوجه الثالث : يرى أصحاب هذا القول، أن الثـيء الذى يتأتى به شـيء واحد، ولا يتأتى منه ضده، يكون الحاصل منه حاصلاً بالطبع لا بالاختيار، كالثُج مثلاً فإنه يحصل به التبريد دون التسخين، وكالنار التي هي علـى العكس من ذلك، فلو كاتت القدرة الحادثة لا تصلح للضدين، لأدى ذلك إلى

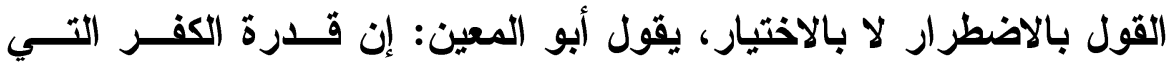
وجدت في الكافر لو كانت غير صالحة للإيمان، ولا تصلح إلا للكفر، لكان لا يتمكن الكافر المختص بقدرة الكفر أن ينفك عن الكفر وأن يعدل عنــه، وأن يأتي بالإيمان، وهذا بدوره يؤدى إلى أمرين باطلين، تكليف ما لـيس في الوسع، أو ارتفاع الفرق بين المضطر، والقادر، والفرق بينهما معلوم

بالاضطر ار (r) هذا وبرغم محاولة هذا الفريق الاحتجاج على قوله، ومن محاولته تفادى اعتراضات قد ترد على القول الأول - إلا أننا نرى- من جانبنا- أن القول الأى تبناه الأشـاعرة وبعض الماتريدية من أن القدرة الحادثــة لا تصــلح للضدين، أسلم وأولى بالقبول، ذلك - لأنه كما ذكرنا قبل - يتسق تمامــاً مع ما أجمع عليه الأشثاعرة والماتريدية، من كون القدرة الحادثة مقارنـــة 
$\wedge \wedge \vee$

للمقدور بها، وما تحرج منه هذا الفريق من لزوم عدم الفرق بين الفعـل

المقدور والفعل الاضطراري، فقد بينا اندفاعه فيما سبث. 
نقف هنا لنرصد أهم النقاط التي توصلنا اليها خلال البحث ومن ذلك: 1- لا شكك في فساد قول الجبرية، ويأتي فساد قول الجبرية من نفيهم عن الإنسان القدرة والإرادة أصلا، مما لزمه أن تكون الأفعـال كلهـا عندهم بمثابة واحدة، لا فرق بين ما هـو اختيـاري وبـين مــا هـو

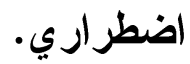

ץ- وكذلك رأى القدرية الأوائل، نجد أنه هو الآخر قد حمل دليل فساده حيث تصادم هذا القول مع ما ثبت لله تعالى من شمول العلم، وعمـوم تعلقه بكل شيء واجب أو جائز، أو مستحيل، وفى ذلك ما يكفى دلـيلاً على فساد هذا القول. r- ثمة اتفاق يجمع الأثثاعرة والماتريدية يتمثل في رفض كل منهما لقول كل من الجبرية، والمعتزلة، كحل لمسألة الإسانيات، وكنلك فـي اتفاقهما على أن العبد غير فاعل استقلالاً. ع - دارت أقوال الأثشاعرة والماتريدية بالنسبة للإنسانيات فـي هـــا الإطار المتوسط بين أقوال الجبرية، وأقوال المعتزلة. ه- - راعى الأثثاعرة و الماتريدية ما ثبت من عموم خالقيته تعالى لكـلـ شيء، وما دل عليه الثرع من أن للإنسان أفعالاً كلف بها، أمراً ونهياً، فحققا الأمرين معا وقالو ا بالكسب. 


\section{$\wedge \wedge 9$}

ونرى أنه بتبني الأشاعرة والماتريدية القول بأن الفعل الإساني خلــق لله تعالى وكسب للعباد، حافظ الأثثاعرة والماتريدية بذلك على ما أطبق عليه السلف من أن ما شاء الله كان، وما لم يشأ لم يكن.

وبناء على ذلك نرى أن موقف الأشاعرة و الماتريدية من مسألة أفعال الإنسان، هو أقرب المواقف للحق، وذلك لتفاديه ما يلزم علــى بقيــة المو اقف من محظورات. وآخر دعوانا أن الحمد الله رب العالمين 
ثبت بأهم المصادر والمراجع

ا- - ابن المنير، أحمد بن محمد الإسكندري، الاتتصاف فيما تضــــه الكثاف من الاعتز ال، بهامش تفسير الكشاف للزمخشري، ط دار الفكر

r- - ابن الهمام، كمال الدين، المسايرة في علم الكلام، تحقيق محمـــ محيى الادين عبد الحميد، ط مكتبة المحمودية، الأولى. r- أبو دقيقة، الشيخ محمود، القول السديد في علم التوحيد، تحقيق أ.د// عوض الله جاد حجازي ط مجمع البحوث الإسلامية، ه 1 ـ أهـ. ع- أبو زهرة، محمد أبو زهرة، تاريخ المــذاهب الإســلامية، ط دار الفكر العربي، بدون. ه- الإسفر اييني أبو المظفر طاهر بن شاهفور، التبصير في الــدين، تحقيق كمال يوسف الحوت، ط عالم الكتب، بيروت، الأولى، بـ ــ اهـ צ- الأشعري، أبو الحسن على بن إسماعيل، اللمع في الرد على أهل الزيغ والبدع، تحقيق د/ حمودة غرابة، طا إك أهـ. -V الأشعري، أبو الحسن على بن إسماعيل، مقـالات الإســلاميين، تحقيق محمد محيى الاين عبد الحميد، ط المكتبة العصــرية، بيـروت، $.1 \leq 11$

1- الأصفهاني، حسين بن محمد، المفردات في غريب القرآن، تحقيق محمد سيد الكيلاني، ط دار المعرفة، بيروت، لبنان، بدون. 
9- الألوسى شهاب الاين محمود شكري، روح المعاني فــي تفسـير القرآن العظيم، ط إدارة الطباعة المنيرية، بيروت، لبنان. • 1- الآمدي، سيف الدين، أبكار الأفكار في أصول الدين، تحقيـقـى أ.د/

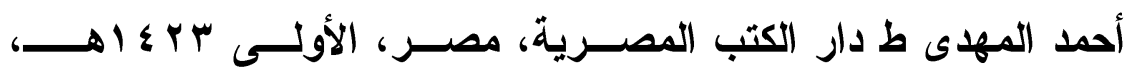
pror 1 - الإيجي، عبد الرحمن بن أحمد، المواقف في علم الكــلام بثــــح السيد الثريف الجرجاني، ط بيروت، الأولى، 9 اءـ أ.

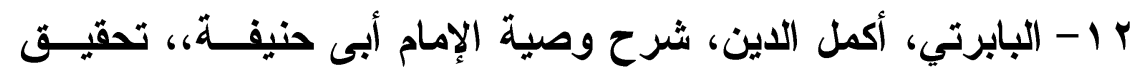
ودراسة أربيع خليفة عبد الصادق، رسالة ماجستير مخطوطة، بكليــة

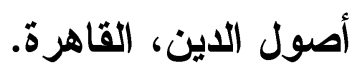
r ا - الباقلاتي، أبو بكر بن الطيب، تمهيد الأوائل وتلذـيص الــلايل،

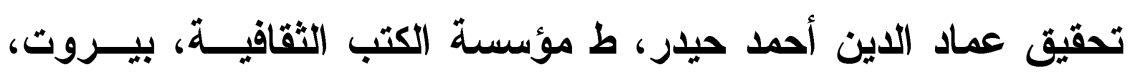
. I I $1 \varepsilon$

ـ ا - البزدوي، أبو اليسر محمد بن عبد الكريم، أصول اللاين، تحقيـق

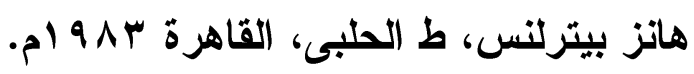

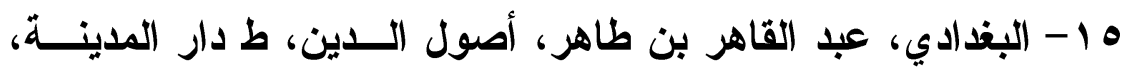

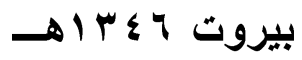

14

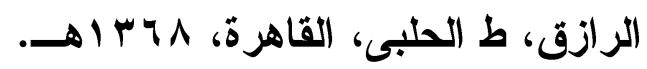


IV - البيجوري، إبراهيم بن أحمد، تحفة المريد على جوهرة التوحيد،

$$
\text { ط } 7 \text {. }
$$

1 ا - البيهقي، أبو بكر أحمد بن الحسين، الاعتقاد على مـذهب أهـل السنة والجماعة، ط دار السلام العالمية القاهرة بدون. 9 ا - التفتازاني، سعد الاين بن عمر، شرح المقاصد في أصول الاين،

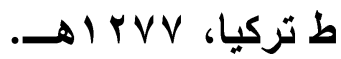

• r - الجوينـي، عبد الملكك بن عبد الله، الإرشاد إلـــى قواطـــع الأدلــة، تحقيق د/محمد يوسف موسى، ط الخانجي، القاهرة، ، 9 ام. ا Y - الجويني، عبد الملك بن يوسف، العقيدة النظامية، تحقيق الثــيخ محمد زاهد الكوثري، نشر المكتبة الأزهرية، ب إ؛ اهــ. r r - حمودة غزابة الاكتور، الأشعري أبو الحسن، ط مجمع البحـوث

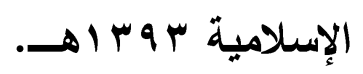

rr - الرازي، فخر الاين محمد بن عمر، الأربعين في أصول الاين، ط مكتبة الكليات الأزهرية، القاهرة، 7 . ع الهـ. ع - الرازي، فخر الدين محمد بن عمر، مفاتيح الغيب، ط دار الفكـر، بيروت، ع أ أهـ.

ه Y - الزمخشري، جار الله أبو القاسم، الكشاف عن حقـائق التنزيــل وعيون الأقاويل، ط دار الفكر، بدون.

צ ץ - زهدي، الاكتور زهدي جار الله، المعتزلة، ط مصر، 7 ج اهـــ 
rV خريدة أبى البركات الدردير في التوحيد، ط أولى، القاهرة، اسب اهـــ ^r - السنوسي، محمد بن يوسف، عمدة عقيدة أهل التوحيد، الكبرى،

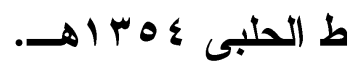
9 - الثرقاوي، عبد الله، حاثية الثرقاوي على الهـهدي، ط عيسى الحلبح القاهرة. • r- الشهرستاني، محمد بن عبد الكريح، الملل والنحل، تحقيق أ/ أحمد فهمى محمد، ط دار الكتب العلمية، بيروت.

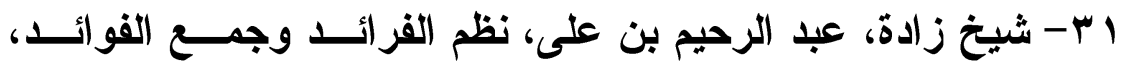
تحقيق ودراسة أ/جميل إبراهيم السيد، رسالة ماجستير، مخطوطة بكلية أصول الاين بالقاهرة، تحت رقم اس • ب. r r- الصابوني، نور الاين أحمد بن أبى بكر، البداية من الكفاية فـي أصول الدين، تحقيق د/ فتح الله خليـفـ، ط دار المعــارف، القــاهرة، . 1979 r الحديثة، القاهرة، بدون. ع س- عبد الحليم محمود الاكتور، التفكير الفلسفي في الإســلام، ط دار

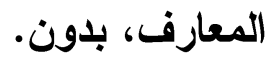

هـ - الغزالي، محمد بن محمد حجة الإسلام، الاقتصاد فــي الاعتقـــاد، تحقيق الثيخ محمد مصطفى أبو العلا، ط مكتبة الجندي، القاهرة. 


\section{$\wedge 9 \varepsilon$}

צr- قاضى القضاة عبد الجبار بن أحمد، المغتى في أبــواب التوحيـــ و العدل، ط المؤسسة المصرية العامة للتأليف. TV - قاضى القضاة عبد الجبار بن أحمد، تنزيه القرآن عن المطــاعن، ط دار النهضة الحديثة، بيروت.

^r- قاضى القضاة عبد الجبار بن أحمد، شــرح الأصـــول الخمســة، تحقيق د/ عبد الكريم عثمان، ط مكتبة وهبة، 1 . ع اهـ q r- الكور اني، إبراهيم ابن حسن، قصد السبيل فـي حـل مشــكلات

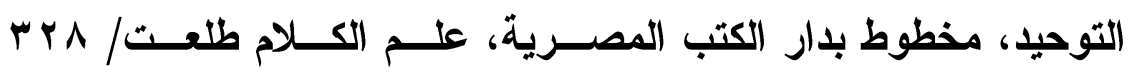

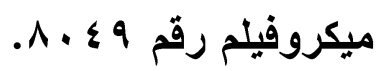

• ع - الكوراني، إبراهيم ابن حسن، مسلك السداد إلى مسألة خلق أفعال العباد، مخطوط بدار الكتب المصرية عقائد تيمور/ rov ميكروفيلم رقم . . 99 rV

إ- الماتريلى، أبو منصور محمد، كتاب التوحيد، تحقيق د/ فتح الله خليف، ط دار الجامعات المصرية، بلون. ץ צ - النسفي، أبو البركات، عمدة العقائد، تحقيق ودراسة أ/ إبــراهيم عبد الثافي، رسالة ماجستير مخطوطة، بكلية أصول الاين، القــاهرة،

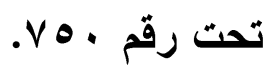

r ـ - النسفي، أبو المعين محمد بن ميمون، تبصرة الأدلة في أصــول الاين، تحقيق كلود سـلامه، ط المعهـــد العلمــي القرنســي للار اســات

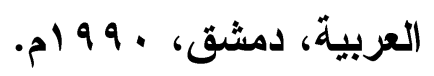


Almasadir \&almarajie

1- abin almunir, 'ahmad bin muhamad al'iiskandari, alaintisaf fima tadamanah alkashaf min alaietizali, bihamish tafsir alkishaf lilzumakhshari, t dar alfikr biduni.

2- abn alhamam, kamal aldiyn, almusayarat fi eilm alkalami, tahqiq muhamad mahyaa aldiyn eabd alhamid, t maktabat almahmudit, al'uwlaa.

3- 'abu daqiqati, alshaykh mahmud, alqawl alsadid fi eilm altawhida, tahqiq 'a.di/ eawad allah jad hijazi t majamae albuhuth al'iislamiati, 1415hi.

4-'abu zahrata, muhamad 'abu zahrata, tarikh almadhahib al'iislamiati, t dar alfikr alearabii, biduni.

5- al'iisfrayiniu 'abu almuzafar tahir bin shahfur, altabsir fi aldiyn, tahqiq kamal yusif alhut, t ealim alkutab, bayrut, al'uwlaa, 1403h

6- al'asheari, 'abu alhasan ealaa bin 'iismaeil, allamae fi alradi ealaa 'ahl alziygh walbidae, tahqiq du/ hamuwdat gharabata, ta1411h.

7- al'asheari, 'abu alhasan ealaa bin 'iismaeil, maqalat al'iislamiiyna, tahqiq muhamad mahyaa aldiyn eabd alhamid, t almaktabat aleasriati, bayrut, $1411 \mathrm{~h}$. 
8- al'asfahani, husayn bin muhamad, almufradat fi ghurayb alqurani, tahqiq muhamad sayid alkilany, $t$ dar almaerifati, bayrut, lubnan, bidun.

9- al'alusaa shihab aldiyn mahmud shakri, ruh almaeani fi tafsir alquran aleazimi, $t$ 'iidarat altibaeat almuniriati, bayrut, lubnan.

10- alamdi, sayf aldiyn, 'abkar al'afkar fi 'usul aldiyn, tahqiq 'a.da/ 'ahmad almahdaa $t$ dar alkutub almisriatu, masir, al'uwlaa 1423h, 2002m.

11- al'iiji, eabd alrahman bin 'ahmadu, almawaqif fi eilm alkalam bisharh alsayid alsharif aljirjani, t bayrut, al'uwlaa ‘1419.

12- albabirti, 'akmal aldiyn, sharh wasiat al'iimam 'abaa hanifat,, tahqiq wadirasat 'a/rbie khalifat eabd alsaadiq, risalat majistir makhtutatan, bikuliyat 'usul aldiyn, alqahirati.

13- albaqlani, 'abu bakr bin altayb, tamhid al'awayil watalkhis aldalayil, tahqiq eimad aldiyn 'ahmad haydar, $t$ muasasat alkutub althaqafiati, bayrut, $1414 \mathrm{~h}$.

14- albizdiwi, 'abu alyusr muhamad bin eabd alkarim, 'usul aldiyn, tahqiq hanz bitirlins, $t$ alhalbaa, alqahirat $1983 m$. 
15- albaghdadi, eabd alqahir bin tahir, 'usul aldiyn, $t$ dar almadinati, bayrut $1346 \mathrm{~h}$

16- albyady, kamal aldiyn 'ahmadu, 'iisharat almarami, tahqiq yusif eabd alraaziq, $t$ alhalbaa, alqahiratu, 1368hi. 17- albijuri, 'iibrahim bin 'ahmadu, tuhfat almurid ealaa jawharat altawhidi, t 1406hi.

18- albihaqi, 'abu bakr 'ahmad bin alhusayn, alaietiqad ealaa madhhab 'ahl alsunat waljamaeati, $t$ dar alsalam alealamiat alqahirat bidun.

19- altiftazani, saed aldiyn bin eumra, sharh almaqasid fi 'usul aldiyn, t turkia, 1277hi.

20- aljuini, eabd almalik bin eabd allah, al'iirshad 'iilaa qawatie al'adilati, tahqiq du/muhamad yusif musaa, $t$ alkhanji, alqahirati, $1950 \mathrm{~m}$.

21- aljuini, eabd almalik bin yusif, aleaqidat alnizamiati, tahqiq alshaykh muhamad zahid alkuthari, nashr almaktabat al'azhariati, 1412h.

22- hmudat gharabat aldukturu, al'asheariu 'abu alhasan, t majamae albuhuth al'iislamiat 1393hi.

23- alraazi, fakhr aldiyn muhamad bin eumra, al'arbaein fi 'usul aldiyni, t maktabat alkuliyaat al'azhariati, alqahiratu, 1406hi. 
24- alraazi, fakhr aldiyn muhamad bin eumra, mafatih alghib, t dar alfikri, bayrut, 1414h.

25- alzamakhshari, jar allah 'abu alqasama, alkashaf ean haqayiq altanzil waeuyun al'aqawili, $t$ dar alfikri, biduni. 26- zahdi, alduktur zahdi jar allah, almuetazilati, $t$ masr, 1366h.

27- alsabaei, mahmud 'abu alsueud salihi, hashiat alsubaeiu ealaa sharh kharidat 'abaa albarakat aldardir fi altawhidi, t 'uwlaa, alqahirati, 1331hi.

28- alsanusi, muhamad bin yusif, eumdat eaqidat 'ahl altawhidi, alkubraa, $t$ alhalbaa 1354hi.

29- alsharqawi, eabd allah, hashiat alsharqawi ealaa alhadhadi, $t$ eisaa alhalbaa alqahirati.

30- alshahristani, muhamad bin eabd alkrim, almilal walnahla, tahqiq 'a/ 'ahmad fahmaa muhamad, t dar alkutub aleilmiati, bayrut.

31- shikh zadat, eabd alrahim bin ealaa, nuzam alfarayid wajamae alfawayida, tahqiq wadirasat 'a/jamil 'iibrahim alsayida, risalat majstir, makhtutat bikuliyat 'usul aldiyn bialqahirati, taht raqm 2031.

32- alsaabuni, nur aldiyn 'ahmad bin 'abaa bakr, albidayat min alkifayat fi 'usul aldiyn, tahqiq du/ fath allah khalif, t dar almaearifi, alqahirata, 1969m. 
33- tash kubraa zadat, 'ahmad bin mustafaa, miftah alsaeadat $t$ dar alkutub alhadithati, alqahirati, bidun. 34- eabd alhalim mahmud aldukturu, altafkir alfalsafiu fi al'iislami, t dar almaearifi, biduni.

35- alghazali, muhamad bin muhamad hujat al'iislami, alaiqtisad fi alaietiqadi, tahqiq alshaykh muhamad mustafaa 'abu aleala, t maktabat aljundi, alqahirati.

36- qadaa alqudaat eabd aljabaar bin 'ahmadu, almughanaa fi 'abwab altawhid waleadli, $t$ almuasasat almisriat aleamat liltaalifi.

37- qadaa alqudaat eabd aljabaar bin 'ahmad, tanzih alquran ean almataeini, t dar alnahdat alhadithati, bayrut.

38- qadaa alqudaat eabd aljabaar bin 'ahmad, sharh al'usul alkhamsati, tahqiq du/ eabd alkarim euthman, $t$ maktabat wahbata, $1408 \mathrm{~h}$

39- alkurani, 'iibrahim abn hasan, qasad alsabil fi hali mushkilat altawhidi, makhtut bidar alkutub almisriati, eilm alkalam talaeat/ 328 mikrufilm raqm 8049. 40- alkurani, 'iibrahim aibn hasana, maslak alsadad 'iilaa mas'alat khalq 'afeal aleabadi, makhtut bidar alkutub almisriat eaqayid timur/ 257 mikrufilm raqm 29937. 
41- almatiridaa ،'abu mansur muhamad, kitab altawhida, tahqiq du/ fath allah khalif, t dar aljamieat almisriati, biduni.

42- alnsfi, 'abu albarkati, eumdat aleaqayidi, tahqiq wadirasat 'a/ 'iibrahim eabd alshaafi, risalat majistir makhtutatun, bikulyat 'usul aldiyn, alqahirati, taht raqm 750.

43- alnsfi, 'abu almueayn muhamad bin mimun, tabsirat al'adilat fi 'usul aldiyn, tahqiq klud salamuhu, t almaehad aleilmiu alfaransiu lildirasat alearabiati, dimashqa, 1990m. 